\title{
Identification of the Immediate-Early Genes of Cyprinid Herpesvirus 2
}

\author{
Ruizhe Tang ${ }^{1,2,3}$, Liqun Lu ${ }^{1,2,3}$, Beiyang Wang ${ }^{4}$, Jiao $\mathrm{Yu}^{4}$ and Hao Wang ${ }^{1,3, *(\mathbb{D}}$ \\ 1 National Pathogen Collection Center for Aquatic Animals, Shanghai Ocean University, Shanghai 201306, \\ China; m180100211@st.shou.edu.cn (R.T.); lqlv@shou.edu.cn (L.L.) \\ 2 Key Laboratory of Freshwater Aquatic Genetic Resources, Ministry of Agriculture Shanghai Ocean \\ University, Shanghai 201306, China \\ 3 National Demonstration Center for Experimental Fisheries Science Education, Shanghai Ocean University, \\ Shanghai 201306, China \\ 4 China Society of Fisheries, Beijing 100000, China; baye916@163.com (B.W.); yjsnlmc@163.com (J.Y.) \\ * Correspondence: h-wang@shou.edu.cn; Tel.: +86-021-6190-0453
}

Received: 28 July 2020; Accepted: 3 September 2020; Published: 7 September 2020

\begin{abstract}
Cyprinid herpesvirus 2 (CyHV-2), which infects goldfish and crucian carp causing high mortality, is an emerging viral pathogen worldwide. The genome of CyHV-2 is large and comprises double-stranded DNA, including several genes similar to cyprinid herpesvirus 1, ictalurid herpesvirus-1, cyprinid herpesvirus 3, and ranid herpesvirus-1. Genes of DNA viruses are expressed in three temporal phases: immediate-early (IE), early (E), and late (L) genes. Viral IE genes initiate transcription as soon as the virus enters the host, without viral DNA replication. IE gene products enable the efficient expression of $\mathrm{E}$ and $\mathrm{L}$ genes or regulate the host to initiate virus replication. In the present study, five IE genes of CyHV-2 were identified, including open reading frame (ORF)54, ORF121, ORF141, ORF147, and ORF155. Time course analysis and reverse transcription polymerase chain reaction confirmed five IE genes, thirty-four E genes, and thirty-nine L genes. In addition, all $150 \mathrm{ORF}$ identified in the CyHV-2 genome are transcribed, and are expressed in chronological order, similar to other herpesviruses. This study is the first to identify the IE genes of CyHV-2, which will provide more information for viral molecular characterization.
\end{abstract}

Keywords: cyprinid herpesvirus 2; immediate-early gene; Carassius auratus gibelio; ORF121

\section{Introduction}

Cyprinid herpesvirus 2 (CyHV-2), a pandemic pathogen for Carassius auratus, (e.g., crucian carp and goldfish) is a large, enveloped DNA virus that causes herpes viral hematopoietic necrosis (HVHN) disease. HVHN disease causes acute gill hemorrhage and high mortality, leading to a serious threat to crucian carp and goldfish populations. The disease has spread across the world and can be found in Japan [1], the USA [2], the UK [3], China [4], New Zealand [3], and Australia [5]. CyHV-2 is a member of the Alloherpesviridae family (genus Cyprinivirus), which also comprises cyprinid herpesvirus 3 (CyHV-3) and carp pox virus (CyHV-1). Characteristically, CyHV-2 and CyHV-3 can establish acute, persistent, and latent infection in their host, similar to other herpesviruses [6]. Symptomless surviving fish in populations with persistent infection can promote viral spread, representing a major route for CyHV-2 transmission that affects the global trade of healthy and infected goldfish. Recently, the complete genomes of seven CyHV-2 isolates have been published, including ST-J1 (NC019495, 290,304 bp, 150 ORFs), SY-C1 (KM200722, 289,365 bp, 140 ORFs), SY (KT387800, 290,455 bp, 150 ORFs), YC-01 (MN593216, 275,367 bp, 150 ORFs), YZ-01 (MK260012, 288,076 bp, 148 ORFs), CNDF-TB2015 (MN201961, 288,321 bp, 181 ORFs), and CaHV (KU199244, 275,348 bp, 150 ORFs). The above complete genomes 
have improved our understanding of the biology of CyHV-2. However, the molecular pathogenesis of CyHV-2 remains poorly understood.

Like many other DNA viruses, herpesvirus genes are classified into three distinct phases: immediate-early (IE) genes, early (E) genes, and late (L) genes. Immediate-early genes play a key role in the regulation of $\mathrm{E}$ and $\mathrm{L}$ genes. In addition, many IE genes code for regulatory proteins that are essential to regulate the physiological state of the host cell to enhance viral replication [7]. Fifteen CyHV-3 IE genes were identified using a fibroblast-like cell line as an in vitro infection system together with cycloheximide (CHX) as an inhibitor [8]. However, among all sequenced alloherpesviruses, twelve genes (ORF33, ORF46, ORF47, ORF61, ORF71, ORF72, ORF78, ORF79, ORF80, ORF90, ORF92 and ORF107 referred as core genes) are conserved significantly [9]. The expression order of the open reading frames (ORFs) identified in CyHV-2 remains unknown.

In the present study, we identified 5 IE genes, 34 E genes, and $39 \mathrm{~L}$ genes from the CyHV-2 genome using high-throughput sequencing combined with $\mathrm{CHX}$ and Cytarabine (Ara-C) inhibitors, similarly to other herpesviruses. The transcription of IE genes, such as ORF54, ORF121, ORF141 and ORF155 of CyHV-2 started soon after infection. By 8 h, CyHV-2 had completed viral genome replication.

\section{Materials and Methods}

\subsection{Cell Cultures and Virus Preparation}

The RyuF-2 cell line was generously provided by Dr. Motohiko Sano (Tokyo University of Marine Science and Technology). This cell line, which was derived from a Ryukin goldfish caudal fin, can be infected with CyHV-2 and can be used for in vitro virus replication. These cells were maintained at $22{ }^{\circ} \mathrm{C}$ and cultivated in modified tissue culture Medium199 (Gibco, Grand Island, NY, USA). Fetal bovine serum (FBS; 10\%; Gibco) and 2\% Penicillin-Streptomycin (Gibco) were supplemented to the medium for stable cell culture. CyHV-2 was first isolated in Japan in 1999 from diseased goldfish [10]. Viruses were collected from infection RyuF-2 cells at seven days post-infection. Cells and cell debris were removed by centrifugation at $12,000 \times g$ for $20 \mathrm{~min}$ at $4{ }^{\circ} \mathrm{C}$. The supernatant was filtered through a $0.22-\mu \mathrm{m}$ filter unit to collect the virus. The virus titer was quantified by gradient dilution counting. The harvested virus was aliquoted and placed at $-80{ }^{\circ} \mathrm{C}$ for subsequent experiments.

\subsection{Cell Viability Test}

The viability of RyuF-2 cells was tested using a Muse ${ }^{\circledR}$ Count \& Viability kit (Merck KGaA, Darmstadt, Germany) after treatment with different concentrations of inhibitors for $14 \mathrm{~h}$ (time elapsed after $4 \mathrm{~h}$ of pretreatment of cells, $2 \mathrm{~h}$ for CyHV-2 incubation, and $8 \mathrm{~h}$ post infection). The concentrations of CHX and Ara-C used in this test were $3 \mu \mathrm{g} / \mathrm{mL}, 6 \mu \mathrm{g} / \mathrm{mL}, 9 \mu \mathrm{g} / \mathrm{mL}, 12 \mu \mathrm{g} / \mathrm{mL}, 15 \mu \mathrm{g} / \mathrm{mL}, 30 \mu \mathrm{g} / \mathrm{mL}$, $60 \mu \mathrm{g} / \mathrm{mL}, 90 \mu \mathrm{g} / \mathrm{mL}, 120 \mu \mathrm{g} / \mathrm{mL}, 150 \mu \mathrm{g} / \mathrm{mL}$, and $30 \mu \mathrm{g} / \mathrm{mL}, 60 \mu \mathrm{g} / \mathrm{mL}, 90 \mu \mathrm{g} / \mathrm{mL}, 120 \mu \mathrm{g} / \mathrm{mL}, 150 \mu \mathrm{g} / \mathrm{mL}$, $180 \mu \mathrm{g} / \mathrm{mL}, 210 \mu \mathrm{g} / \mathrm{mL}, 240 \mu \mathrm{g} / \mathrm{mL}, 270 \mu \mathrm{g} / \mathrm{mL}, 300 \mu \mathrm{g} / \mathrm{mL}$. All cells and debris from three biological replicates in the wells were re-suspended in sterile filtered phosphate-buffered saline (PBS) at $10^{6}$ cells $/ \mathrm{mL}$. Following the manufacturer's instructions, $50 \mu \mathrm{L}$ of cell suspension was mixed with $450 \mu \mathrm{L}$ of Count \& Viability Reagent and placed in the dark for $5 \mathrm{~min}$ at room temperature. Using the Muse ${ }^{\circledR}$ Cell Analyzer, we obtained cell viability and cell count data. To determine the correct parameters for Muse ${ }^{\circledR}$ gating, a suspension of well-grown cells at $10^{6}$ cells $/ \mathrm{mL}$ was used to set the viability profile and to determine the gates for the Muse ${ }^{\circledR}$ Cell Analyzer and the Cell Count and Viability assay Kit.

\subsection{Protein and DNA Synthesis Inhibitor Treatment of Cultured Cells}

RyuF-2 cells were grown in six-well plates at $10^{6}$ cells/well. CHX was used to inhibit protein synthesis and cytosine- $\beta$-D-arabinofuranoside (Ara-C) was used to inhibit DNA synthesis (both Sigma, St. Louis, MO, USA). After $4 \mathrm{~h}$ of treatment with inhibitors, cells comprising the infection group were treated with CyHV-2 (MOI (Multiplicity of infection) $=1$ ) for $2 \mathrm{~h}$ in the presence of the inhibitors. The virus was removed and the cells were overlaid with fresh media with the same concentration of added inhibitor. In all experiments, the cells at this stage were designated as being at time 0 . 


\subsection{Nucleic Acid Extraction and Quantitative Real-Time Reverse Transcription PCR (qRT-PCR) Analysis}

Total RNA from RyuF-2 samples $\left(1 \times 10^{6}\right.$ cells) was extracted using $1 \mathrm{~mL}$ of the TRIzol Reagent (Invitrogen, Waltham, MA, USA), and subjected to purification using phenol/chloroform and ethanol precipitation. A Nanodrop instrument (ND-1000; Nanodrop Technologies, Wilmington, DE, USA) was used to quantify the RNA. A 5- $\mu$ g sample of RNA was used to generate cDNA using PrimeScript RT Master Mix (Takara, Shiga, Japan) for quantitative real-time PCR (qPCR) and transcriptome sequencing. PrimeSTAR Max DNA Polymerase (Takara, Japan) was used to amplify $1 \mu \mathrm{L}$ of the resultant cDNAs. Specific sets of primers for each ORF were designed using Primer Premier 5.1 (Premier Biosoft, Palo Alto, CA, USA; Table 1) according to the CyHV-2 genome sequence (GenBank: NC_019495) [11]. The reactions contained $25 \mu \mathrm{L}$ of Prime STAR Max Premix ( $2 \times), 1 \mu \mathrm{M}$ forward/reverse primers, and $500 \mathrm{ng}$ of cDNA. Thermal cycling included one cycle of initial activation at $98^{\circ} \mathrm{C}$ for $3 \mathrm{~min}$, followed by 34 cycles at $98{ }^{\circ} \mathrm{C}$ for $10 \mathrm{~s}, 56{ }^{\circ} \mathrm{C}$ for $5 \mathrm{~s}$, and $72{ }^{\circ} \mathrm{C}$ for $15 \mathrm{~s}$, and a final extension at $72{ }^{\circ} \mathrm{C}$ for $10 \mathrm{~min}$. PCR products $(10 \mu \mathrm{L})$ were subjected to agarose gel electrophoresis to show that the molecular mass of each PCR product was related to the appropriate viral DNA sequence. Electrophoresis comprised a 1.5\% agarose gel, $1 \times$ TAE (40 mM Tris-acetate $\mathrm{pH} 8$ and $1 \mathrm{mM}$ EDTA), 2000 DNA Marker (Takara) and nucleic acid dye (Tanon ${ }^{\mathrm{TM}}$, China). Actin and ORFs of CyHV-2 were used as controls to check that the amplified genes were present among the viral transcripts. The primers derived from actin was used successfully for PCR with cDNA prepared from infected and non-infected cells as the template.

Table 1. Oligonucleotide primers and conditions for PCR and Real-time PCR.

\begin{tabular}{|c|c|c|c|c|}
\hline PCR & Gene Name & Nucleotide Sequence $\left(5^{\prime}-3^{\prime}\right)$ & $\begin{array}{l}\text { Amplicon } \\
\text { Sizen (bp) }\end{array}$ & $\operatorname{Tm}\left({ }^{\circ} \mathrm{C}\right)$ \\
\hline 1 & ORF1 & $\begin{array}{l}\text { F:CTACAGAAGCCTGCCACC } \\
\text { R:TCCGTGGAGTCTGGTCTG }\end{array}$ & 1341 & 55 \\
\hline 2 & ORF2-A & $\begin{array}{l}\text { F:ACCACCACCTCTGCGAAAC } \\
\text { R:ATTGTGCCCTGTGCGTTT }\end{array}$ & 311 & 55 \\
\hline 3 & ORF3 & $\begin{array}{l}\text { F:CGTGTATGGAATCCCTCG } \\
\text { R:TGCCTCTGTGGCTTGTAT }\end{array}$ & 1035 & 55 \\
\hline 4 & ORF5 & $\begin{array}{l}\text { F:CGCTGAACCTGAAACCCTCC } \\
\text { R:GCGTTCCCTGTGGTTCCTG }\end{array}$ & 404 & 60 \\
\hline 5 & ORF6 & $\begin{array}{l}\text { F:TGGCTTTCTGCTGGAGGTG } \\
\text { R:CACCAGCACCAACCACTCA }\end{array}$ & 824 & 60 \\
\hline 6 & ORF7 & $\begin{array}{l}\text { F:CGGTTCTCAGCCAGTTCG } \\
\text { R:TGCTTGACCCTCCATCCC }\end{array}$ & 355 & 60 \\
\hline 7 & ORF8 & $\begin{array}{l}\text { F:CAGGGACCAGACCGAAGACA } \\
\text { R:CGTCCTCGTCTCCAGGGTCT }\end{array}$ & 509 & 60 \\
\hline 8 & ORF10 & $\begin{array}{l}\text { F:AGCAGCAGGTGGCTTCGGATAG } \\
\text { R:GCGGCGTGGATTGTTGGAGT }\end{array}$ & 1643 & 60 \\
\hline 9 & ORF16 & $\begin{array}{l}\text { F:CAAGGGTTCAAGAAAGTAA } \\
\text { R:TTGGAGCGTCTATGGTAT }\end{array}$ & 537 & 50 \\
\hline 10 & ORF17 & $\begin{array}{l}\text { F:CTCGGCGTAGATGTAAGTG } \\
\text { R:GCCTCTGTAACGGATGAA }\end{array}$ & 1314 & 50 \\
\hline 11 & ORF19 & $\begin{array}{l}\text { F:CGAAGGAAACCTGGGAGC } \\
\text { R:CGGGCTCGCTTGTTGACT }\end{array}$ & 471 & 60 \\
\hline 12 & ORF20 & $\begin{array}{l}\text { F:GATGCTGTTGCCGACCTT } \\
\text { R:TGCGACGTTACCGACCTA }\end{array}$ & 543 & 55 \\
\hline 13 & ORF24 & $\begin{array}{c}\text { F:CGAGGGACTCCACAACCG } \\
\text { R:TCAAATCACCCAGACAATACCA }\end{array}$ & 470 & 58 \\
\hline 14 & ORF25-C & $\begin{array}{l}\text { F:CACCCTACCCTCCGAAAT } \\
\text { R:TGAACCGCAATACACCTT }\end{array}$ & 655 & 55 \\
\hline 15 & ORF25-D & $\begin{array}{c}\text { F:AACCAGACCATCACTCGCATAG } \\
\text { R:CCACCACTTGGGCTCCTC }\end{array}$ & 376 & 60 \\
\hline 16 & ORF33 & $\begin{array}{l}\text { F:AGAGTCCGTGAGTAACCTGTGG } \\
\text { R:GCATCCGACACCACCTTG }\end{array}$ & 507 & 60 \\
\hline 17 & ORF35 & $\begin{array}{c}\text { F:GTGATGCCGACAGAGGACA } \\
\text { R:TGATACTCGGCTCCCTTCT }\end{array}$ & 554 & 60 \\
\hline 18 & ORF41 & $\begin{array}{l}\text { F:TTCTTCTGACGCCAACCA } \\
\text { R:CACGGCTTGGGTAGGTTG }\end{array}$ & 657 & 58 \\
\hline 19 & ORF43 & $\begin{array}{l}\text { F:CCAAGCCGTGCGACATAG } \\
\text { R:GTTGCCGCCAAACATTAC }\end{array}$ & 485 & 58 \\
\hline
\end{tabular}


Table 1. Cont.

\begin{tabular}{|c|c|c|c|c|}
\hline PCR & Gene Name & Nucleotide Sequence $\left(5^{\prime}-3^{\prime}\right)$ & $\begin{array}{l}\text { Amplicon } \\
\text { Sizen (bp) }\end{array}$ & $\operatorname{Tm}\left({ }^{\circ} \mathrm{C}\right)$ \\
\hline 20 & ORF44 & $\begin{array}{l}\text { F:GCGGAGATAATGGAGGTGA } \\
\text { R:CAGGAGTCGGGTTGTTGC }\end{array}$ & 450 & 55 \\
\hline 21 & ORF45 & $\begin{array}{l}\text { F:CCACGGTCAAGCAGGGTA } \\
\text { R:GCGAGGTCGTCGAAATCA }\end{array}$ & 385 & 55 \\
\hline 22 & ORF46 & $\begin{array}{l}\text { F:ATGGGCGTCGTGGATTAC } \\
\text { R:TTCTTGCTGCTGCTGTCG }\end{array}$ & 371 & 55 \\
\hline 23 & ORF47 & $\begin{array}{l}\text { F:TGAATACGCATCCAACTG } \\
\text { R:CGTCCATAGAATCCAACC }\end{array}$ & 437 & 50 \\
\hline 24 & ORF49 & $\begin{array}{l}\text { F:GTGGCGGTAGATGCTTTC } \\
\text { R:CAGGGTCTGATGGTTGGA }\end{array}$ & 305 & 55 \\
\hline 25 & ORF50 & $\begin{array}{l}\text { F:AAGTCGGCAAGGTGTTTC } \\
\text { R:CTTTTGGCGTCTGATGTG }\end{array}$ & 341 & 55 \\
\hline 26 & ORF51 & $\begin{array}{l}\text { F:ACTCGCAGGTGTACTTCAAGGG } \\
\text { R:GGCGACGCTGATGAACACG }\end{array}$ & 533 & 60 \\
\hline 27 & ORF52 & $\begin{array}{l}\text { F:CTACTACGCTTCTACTGCTCT } \\
\text { R:GTGTCGTTGGGTCCTCTT }\end{array}$ & 183 & 50 \\
\hline 28 & ORF54 & $\begin{array}{l}\text { F:AGGGATGGCCGTCTAGTTTT } \\
\text { R:TCGTTGTCGTTGACGAAGAG }\end{array}$ & 432 & 55 \\
\hline 29 & ORF56 & $\begin{array}{l}\text { F:AGTCCATTTACGACGCTA } \\
\text { R:TGGTGAAACGATTTAGGA }\end{array}$ & 499 & 50 \\
\hline 30 & ORF57 & $\begin{array}{l}\text { F:CGAGTTTCCGCCCTACAA } \\
\text { R:CCCAGTGCTGCCAGTGAT }\end{array}$ & 425 & 58 \\
\hline 31 & ORF61 & $\begin{array}{l}\text { F:CGGCATCCAACACCCTAC } \\
\text { R:GAACGAAAGCAGCAGCAA }\end{array}$ & 353 & 55 \\
\hline 32 & ORF62 & $\begin{array}{l}\text { F:CTCCCATTTCCAACCACTC } \\
\text { R:CCTCGTAGACCGACTCCTG }\end{array}$ & 327 & 55 \\
\hline 33 & ORF66 & $\begin{array}{l}\text { F:CTCAAGGATTTCAGGACG } \\
\text { R:TGATGTAAGGGTTGGTGAC }\end{array}$ & 487 & 50 \\
\hline 34 & ORF67 & $\begin{array}{l}\text { F:CACCCAGACTATTTTACGC } \\
\text { R:GCCACTATTGTAGACGATGT }\end{array}$ & 371 & 50 \\
\hline 35 & ORF68 & $\begin{array}{l}\text { F:GGACATACGAAAGGCTACG } \\
\text { R:TTGCGGAGGCTGTGACTT }\end{array}$ & 545 & 58 \\
\hline 36 & ORF69 & $\begin{array}{l}\text { F:GCCACCTACCTAAACGAGC } \\
\text { R:CGTGTTGAGGAAAGCGAGT }\end{array}$ & 319 & 55 \\
\hline 37 & ORF72 & $\begin{array}{l}\text { F:ACGACCAGAAGGACACCAAG } \\
\text { R:GGGGTGGGTAGAGAGGCTAC }\end{array}$ & 429 & 55 \\
\hline 38 & ORF74 & $\begin{array}{l}\text { F:CCGTGATGAACTTGCTGTT } \\
\text { R:GGTACGATTCGGAAGGTAGA }\end{array}$ & 189 & 55 \\
\hline 39 & ORF75 & $\begin{array}{l}\text { F:CGTCTACTATCAGCCGTGTC } \\
\text { R:GCAATAGGTGGTGAGTTCC }\end{array}$ & 313 & 55 \\
\hline 40 & ORF76 & $\begin{array}{l}\text { F:CAGTTTTCGGTTGGTGTTGAGTTGG } \\
\text { R:TTCTGAACGATGATATGAGCGTGAC }\end{array}$ & 554 & 55 \\
\hline 41 & ORF77 & $\begin{array}{c}\text { F:ACGCTGAACATTTCCACTC } \\
\text { R:CGTCCTCGTCCTCTTTGA }\end{array}$ & 417 & 50 \\
\hline 42 & ORF78 & $\begin{array}{l}\text { F:AGGATTCCCAAACAAAGCC } \\
\text { R:GTCATCGTCGGTGAGTTCC }\end{array}$ & 462 & 60 \\
\hline 43 & ORF84 & $\begin{array}{l}\text { F:GCTCAGGGTCACCAATCA } \\
\text { R:ATCCCCGAGTCCGTTCTT }\end{array}$ & 388 & 58 \\
\hline 44 & ORF85 & $\begin{array}{l}\text { F:CACCAGCGGTAGAAGTCG } \\
\text { R:CCACCCATTGTAATAAACG }\end{array}$ & 1004 & 55 \\
\hline 45 & ORF86 & $\begin{array}{l}\text { F:ATCATCCCTTTCCCAGACA } \\
\text { R:GCAAACCGTCCTCAAAGA }\end{array}$ & 534 & 55 \\
\hline 46 & ORF88 & $\begin{array}{l}\text { F:CTGCTGCCGCTGTTTACC } \\
\text { R:TCGCATCCTCGCACTGAC }\end{array}$ & 121 & 58 \\
\hline 47 & ORF89 & $\begin{array}{l}\text { F:ATGGCGGTGGCATTCCTA } \\
\text { R:ATTCGGCGACTGACTTGG }\end{array}$ & 408 & 60 \\
\hline 48 & ORF92 & $\begin{array}{c}\text { F:GAGCCACCTTCCTGTTCC } \\
\text { R:CGTAGAAGAGGGACGAGTG }\end{array}$ & 963 & 55 \\
\hline 49 & ORF95 & $\begin{array}{l}\text { F:CACTGGGCAGAGGTTGAG } \\
\text { R:CAAGTGGTGATCCTGGTCT }\end{array}$ & 574 & 55 \\
\hline 50 & ORF97 & $\begin{array}{l}\text { F:GACGAGCGATGAATACGG } \\
\text { R:GTCTCCGTTGATGGGTCT }\end{array}$ & 574 & 55 \\
\hline 51 & ORF101 & $\begin{array}{l}\mathrm{F}: \text { CGATGACAAGCCTACCGC } \\
\mathrm{R}: \text { GAGCCAGCCAGTCGTTGA }\end{array}$ & 200 & 58 \\
\hline 52 & ORF103 & $\begin{array}{l}\text { F:CCGAACCCGAGTTTTATG } \\
\text { R:ACGCCACAAACACGACCT }\end{array}$ & 567 & 55 \\
\hline
\end{tabular}


Table 1. Cont.

\begin{tabular}{|c|c|c|c|c|}
\hline PCR & Gene Name & Nucleotide Sequence $\left(5^{\prime}-3^{\prime}\right)$ & $\begin{array}{l}\text { Amplicon } \\
\text { Sizen (bp) }\end{array}$ & $\operatorname{Tm}\left({ }^{\circ} \mathrm{C}\right)$ \\
\hline 53 & ORF104 & $\begin{array}{c}\text { F:GTTACTTTCAACCGAGACGC } \\
\text { R:GCCGTCGTTACTGCTGAT }\end{array}$ & 541 & 55 \\
\hline 54 & ORF107 & $\begin{array}{l}\text { F:AACAGGACTGGGAGTTTG } \\
\text { R:GCGACTGAATATGGGATG }\end{array}$ & 230 & 50 \\
\hline 55 & ORF109 & $\begin{array}{l}\text { F:GGTGCGTCCGACTGGTAGA } \\
\text { R:ATGGAGGCGGTGTTCAGC }\end{array}$ & 323 & 58 \\
\hline 56 & ORF111 & $\begin{array}{c}\text { F:AGATTTGGCGAACGAGGAG } \\
\text { R:CGTGTTTGTCGGGCAGGT }\end{array}$ & 411 & 60 \\
\hline 57 & ORF112 & $\begin{array}{l}\text { F:CAACGAATTGACGGCTAA } \\
\text { R:ATGGACCAGAGTGGGAGT }\end{array}$ & 351 & 55 \\
\hline 58 & ORF114 & $\begin{array}{l}\text { F:CCGTCAACGAGTATTCCA } \\
\text { R:CCAGCGTATAGACCCAGA }\end{array}$ & 585 & 50 \\
\hline 59 & ORF115 & $\begin{array}{l}\text { F:TCGGCGAAGAGTCAAAGG } \\
\text { R:CCTGCCACAGCGTAAACA }\end{array}$ & 471 & 55 \\
\hline 60 & ORF120 & $\begin{array}{l}\text { F:GGTGATTGTAGCCAACGAG } \\
\text { R:TTAGAACGACGGTCTGTGAT }\end{array}$ & 448 & 55 \\
\hline 61 & ORF121 & $\begin{array}{l}\text { F:GCTACTACCACCGTTGTTCCA } \\
\text { R:ATCGCTACCATCTTTCTCCTTCT }\end{array}$ & 585 & 55 \\
\hline 62 & ORF125 & $\begin{array}{c}\text { F:GAGAAAGCAGGTCCGAGTT } \\
\text { R:ATCCTCTGGTAGCGTGGG }\end{array}$ & 461 & 55 \\
\hline 63 & ORF126 & $\begin{array}{l}\text { F:TACGCTACAACGGACAAG } \\
\text { R:ATCGCCCAGATCAAAGAC }\end{array}$ & 101 & 50 \\
\hline 64 & ORF128 & $\begin{array}{c}\text { F:CCACTGCTACCGCTTCTA } \\
\text { R:GGCGTACACTCTACCGTCT }\end{array}$ & 719 & 50 \\
\hline 65 & ORF129 & $\begin{array}{c}\text { F:GTTGGGCTGGCATTGTAT } \\
\text { R:CGTTAGAGGTCGGTTCTTTG }\end{array}$ & 314 & 55 \\
\hline 66 & ORF130 & $\begin{array}{c}\text { F:CACCAAACCCGCCTCATA } \\
\text { R:GTATTATTCTGGGTTTGCTTGG }\end{array}$ & 716 & 55 \\
\hline 67 & ORF131 & $\begin{array}{l}\text { F:GAAGACACGGTCCAAGCG } \\
\text { R:CGAGACTCCGATGATTCCTAC }\end{array}$ & 444 & 58 \\
\hline 68 & ORF132 & $\begin{array}{l}\text { F:ACCATCCGTCGTCAACCA } \\
\text { R:AAGCGGTATTGTCGTAGCC }\end{array}$ & 407 & 55 \\
\hline 69 & ORF133 & $\begin{array}{c}\text { F:TAGGCTCATCAGGCACAT } \\
\text { R:GAAGCAGGACAAGACCAAA }\end{array}$ & 319 & 55 \\
\hline 70 & ORF135 & $\begin{array}{l}\text { F:TCCCAGCCCAACAGACAG } \\
\text { R:CCAGAACCCAGGACGAGA }\end{array}$ & 230 & 55 \\
\hline 71 & ORF135A & $\begin{array}{l}\text { F:CACCCAAGGACCCAGAAC } \\
\text { R:CGTCTACGCATCTCAAAGC }\end{array}$ & 489 & 55 \\
\hline 72 & ORF139 & $\begin{array}{l}\text { F:GAGGTGCGGAGAAGTCAG } \\
\text { R:TCTTGTCCTTATCTCCCAGT }\end{array}$ & 1442 & 55 \\
\hline 73 & ORF140 & $\begin{array}{l}\text { F:TGATCCGTTCAAAGATAGA } \\
\text { R:TGATCCGTTCAAAGATAGA }\end{array}$ & 515 & 50 \\
\hline 74 & ORF141 & $\begin{array}{l}\text { F:ATCCGCTTCAAGTGGCTAA } \\
\text { R:GCGTTGAAGATGCGAAGG }\end{array}$ & 739 & 58 \\
\hline 75 & ORF143 & $\begin{array}{c}\text { F:GAGCAGGAGTAGCAGGGTC } \\
\text { R:GCTGATGCGTCTGAGAAT }\end{array}$ & 370 & 55 \\
\hline 76 & ORF145 & $\begin{array}{l}\text { F:TGGCAGTGTCTGTCTTGTC } \\
\text { R:AGATTATACGCCCTTTGG }\end{array}$ & 641 & 50 \\
\hline 77 & ORF146 & $\begin{array}{l}\text { F:GCGTATGGCGTAGGTAGG } \\
\text { R:TGCGAGGATGATGAAGTG }\end{array}$ & 198 & 55 \\
\hline 78 & ORF147 & $\begin{array}{l}\text { F:ATCCGCTTCAAGTGGCTAA } \\
\text { R:GCGTTGAAGATGCGAAGG }\end{array}$ & 739 & 58 \\
\hline 79 & ORF147B & $\begin{array}{l}\text { F:GAGTGGCTGTGGCTGATG } \\
\text { R:GTTGCGGTTGTTTGTCTT }\end{array}$ & 461 & 55 \\
\hline 80 & ORF147C & $\begin{array}{l}\text { F:GAGTGGCTGTGGCTGATG } \\
\text { R:ACGTTGCGGTTGTTTGTC }\end{array}$ & 463 & 55 \\
\hline 81 & ORF151A & $\begin{array}{l}\text { F:ACAGCGAATGGTTGGAAA } \\
\text { R:AACGGTTGAAATGGACAGG }\end{array}$ & 198 & 55 \\
\hline 82 & ORF155 & $\begin{array}{l}\text { F:AAAACTCTGCTATGCGAAAT } \\
\text { R:TGAGGAATGGCTTGACTG }\end{array}$ & 712 & 55 \\
\hline 83 & ORF156 & $\begin{array}{l}\text { F:ACACGCTACCACCGCCTAC } \\
\text { R:CAGCAGCAGCCGTTGAGT }\end{array}$ & 713 & 58 \\
\hline 84 & actin & $\begin{array}{l}\text { F:CACTGTGCCCATCTACGAG } \\
\text { R:CCATCTCCTGCTCGAAGTC }\end{array}$ & 224 & 55 \\
\hline
\end{tabular}


Table 1. Cont.

\begin{tabular}{|c|c|c|c|c|c|}
\hline RT-PCR & Gene Name & Nucleotide Sequence $\left(5^{\prime}-3^{\prime}\right)$ & $\begin{array}{l}\text { Amplification } \\
\text { Efficiency (\%) }\end{array}$ & $\mathbf{r}^{2}$ & Amplicon Size (bp) \\
\hline 1 & actin & $\begin{array}{l}\text { F:CACTGTGCCCATCTACGAG } \\
\text { R:CCATCTCCTGCTCGAAGTC }\end{array}$ & 97.6 & 0.9902 & 224 \\
\hline 2 & ORF7-1 & $\begin{array}{l}\text { F:TGATGACATCGTCCCCCTCT } \\
\text { R:TATGGCTGTGCCTCAACGAG }\end{array}$ & 101.5 & 0.9872 & 149 \\
\hline 3 & ORF24 & $\begin{array}{l}\text { F:TCGACAAGGTCGAAGTGGTG } \\
\text { R:TGCGAACCACTCCTGTAACC }\end{array}$ & 98.7 & 0.9972 & 84 \\
\hline 4 & ORF35 & $\begin{array}{c}\text { F:GTGATGCCGACAGAGGACA } \\
\text { R:TGATACTCGGCTCCCTTCT }\end{array}$ & 101.8 & 0.9880 & 553 \\
\hline 5 & ORF54 & $\begin{array}{l}\text { F:CAAGATTGCATCGAGCGTGG } \\
\text { R:TGTCATCGTCGTCCGCATAG }\end{array}$ & 109.6 & 0.9887 & 281 \\
\hline 6 & ORF57 & $\begin{array}{l}\text { F:GATTCGGGCATCAGAAACGC } \\
\text { R:GCCCATCACGTAGTAGGCTC }\end{array}$ & 96.6 & 0.9988 & 106 \\
\hline 7 & ORF78 & $\begin{array}{l}\text { F:AGGATTCCCAAACAAAGCC } \\
\text { R:GTCATCGTCGGTGAGTTCC }\end{array}$ & 99.0 & 0.9903 & 482 \\
\hline 8 & ORF80 & $\begin{array}{l}\text { F:TCTGGATCTCGTCGAAAGCG } \\
\text { R:GCCCAGCCTGAGAAAGAACT }\end{array}$ & 91.6 & 0.9932 & 107 \\
\hline 9 & ORF89 & $\begin{array}{l}\text { F:CCTGCCCATAAAGGAACGGT } \\
\text { R:GAGCTCGCGTCCATTATCCA }\end{array}$ & 107.8 & 0.9981 & 88 \\
\hline 10 & ORF97 & $\begin{array}{l}\text { F:CGAGACGCGTACGATAACCA } \\
\text { R:AACGCTTTCAAAACGGGACG }\end{array}$ & 113 & 0.9962 & 147 \\
\hline 11 & ORF121 & $\begin{array}{l}\text { F:GGACATCAAATCGGCAGCTC } \\
\text { R:CTCCTCCATGGTCACATCGG }\end{array}$ & 101.4 & 0.9938 & 193 \\
\hline 12 & ORF141 & $\begin{array}{l}\text { F:CAGTGGCTCCCGTACAGTTT } \\
\text { R:TCGATTGCTTCTTGGGGCTT }\end{array}$ & 100.6 & 0.9969 & 114 \\
\hline 13 & ORF147 & $\begin{array}{l}\text { F:GTCCTGTCAGTGTGGTAGCC } \\
\text { R:GTCCATACAGCTGTGGTGCT }\end{array}$ & 97.1 & 0.9991 & 172 \\
\hline 14 & ORF147-C & $\begin{array}{l}\text { F:TCAACCTGCTCGTGTCACTC } \\
\text { R:ACCGTTGCATTACAGTCCGT }\end{array}$ & 97 & 0.9823 & 229 \\
\hline 15 & ORF155 & $\begin{array}{l}\text { F:TCAAGCTGTACTCGTGGCTG } \\
\text { R:GAAGTGACACACCACAACGC }\end{array}$ & 93.5 & 0.9936 & 73 \\
\hline
\end{tabular}

\subsection{Electron Microscopy}

The samples were collected for electron transmission as previously described [12]. According to Section 2.3, RyuF-2 cells were pretreated with the inhibitors at indicated concentration for $4 \mathrm{~h}$, then incubated with CyHV-2 at an MOI of 1 for $2 \mathrm{~h}$. The control group (without inhibitor), the CHX $(12 \mu \mathrm{g} / \mathrm{mL})$ treatment group, and the Ara-C $(300 \mu \mathrm{g} / \mathrm{mL})$ treatment group samples were observed $8 \mathrm{~h}$ post-infection. Slides were fixed in $4 \%$ paraformaldehyde for $30 \mathrm{~min}$ at room temperature and in cold methanol for $10 \mathrm{~min}$ at $-20^{\circ} \mathrm{C}$. Transmission electron microscopy (TEM) images were obtained using a 7000-FA Transmission Electron Microscope (Hitachi, Tokyo, Japan).

\subsection{Sequencing of the $\mathrm{CyHV-2}$ Transcriptome and Bioinformatic Analyses}

To acquire as many transcripts as possible and to minimize the loss of transcripts with low expression, the RNA was sequenced as three parallel samples. Total RNAs of the virus infection group, $\mathrm{CHX}$ treatment group and Ara-C treatment group cells were used for high-throughput sequencing by using the method described in Section 2.4. Transcriptome sequencing was performed using an Illumina HiSeq 4000 sequencer (Illumina San Diego, CA, USA) at Majorbio (Shanghai, China) according to the manufacturer's instruction. The raw data was analyzed using fastx_toolkit_0.0.14 (http://hannonlab.cshl.edu/fastx_toolkit/) for quality assessment statistics to ensure that the quality scores were greater than 20 and the sequencing error rates were less than $0.1 \%$. Then, we used SeqPrep (https://github.com/jstjohn/SeqPrep) and Sickle (https://github.com/najoshi/sickle) software to read the data, remove the linker sequence from the reads, and to discard sequences less than $30 \mathrm{bp}$ after mass trimming, and reads with ambiguous bases ' $\mathrm{N}$ '. The clean data were assembled from scratch using Trinity (https://github.com/trinityrnaseq/trinityrnaseq) to generate contigs and singletons [13]. The clean reads generated from the three libraries (Infection, CHX, Ara-C) were all mapped to the 
reference sequences, which comprised the unigenes assembled from the transcriptome data, using Bowtie2 [14]. CyHV-2 Sequence information was obtained from the ST-JI (GenBank accession no. NC_019495). Phylogenetic trees were built using the neighbor-joining method in MEGA 7 software [15], with the bootstrap value set to 1000. Alignment was performed using DNAMAN software (Lynnon Biosoft, San Ramon, CA, USA). The alloherpesviruses family sequence information was obtained from NCBI (National Center for Biotechnology Information) (SY: KT387800, ST-J1: NC_019495, SY-C1: KM200722, CaHV: KU199244, YC-01: MN593216, CyHV1: NC_019491, CyHV3: NC_009127, IcHV1 (Ictalurid Herpesvirus 1): NC_001493, RaHV2 (Ranid herpesvirus-2): NC_008210, RaHV1 (Ranid herpesvirus-1): NC_008211, and AngHV1 (Anguillid herpesvirus-1): FJ940765).

\subsection{Analysis of CyHV-2 Replication Using PCR and $q P C R$}

As previously described, after treatment with different concentrations of inhibitors, viral gene expression was measured using Prime STAR Max DNA Polymerase amplified cDNA. qPCR was performed to assess the temporal expression of selected CyHV-2 genes. The qPCR reactions contained $12.5 \mu \mathrm{L}$ of TB Green Premix Ex Taq II (2x) (Takara, Japan), $0.4 \mu \mathrm{M}$ forward/reverse primers, and $200 \mathrm{ng}$ cDNA. The thermal cycling program comprised: $95^{\circ} \mathrm{C}$ for $30 \mathrm{~s}$ and then 39 cycles of $95^{\circ} \mathrm{C}$ for $5 \mathrm{~s}$ and $59^{\circ} \mathrm{C}$ for $30 \mathrm{~min}$. The qPCR reactions were repeated three times. To construct a standard curve, serial decimal dilutions were performed using DNA extracted from the virus, and all results were normalized to the relevant actin expression levels. The normalization calculation was performed using the standard procedure for absolute quantification. Statistical significance was calculated using one-way analysis of variance (ANOVA). Values were considered as significant $\left(^{*}\right)$ if they had a $p$ value of 0.01 to 0.05 , very significant $\left.{ }^{* *}\right)$ if they had a $p$ value of 0.001 to 0.01 , and extremely significant $\left.{ }^{* * *}\right)$ if they had of $p$ value 0.0001 to 0.001 .

\section{Results}

\subsection{Screening of CyHV-2 IE Genes}

Viral IE gene expression occurs soon after the virus enters the cell and does not need the expression of additional viral proteins. CHX was used to block new cellular protein synthesis, which would block the transcription of viral $\mathrm{E}$ and L genes, but not IE genes [12]. Ara-C acts by inhibition of DNA synthesis, thus blocking the transcription of viral $\mathrm{L}$ genes. Therefore, $\mathrm{CHX}$ combined with Ara-C could be used to distinguish viral IE, E, and L genes. To construct a screening model to identify viral IE genes, we first optimized the concentrations of CHX and Ara-C. The cytotoxic effects of CHX and Ara-C on RyuF-2 cells were investigated. Cell proliferation and viability were evaluated using a Muse Viability Assay Kit according to the manufacturer's protocol. Figure 1 shows little cytotoxicity when the concentration of $\mathrm{CHX}$ was lower than $15 \mu \mathrm{g} / \mathrm{mL}$. Moreover, none of the concentrations of Ara-C had obvious cytotoxic effect on RyuF-2 cells up to the highest concentrations tested $(300 \mu \mathrm{g} / \mathrm{mL}$ ) (Figure 2). Next, RyuF-2 cells were pre-treated for $4 \mathrm{~h}$ with Ara-C or CHX at different concentrations and then challenged with $\mathrm{CyHV}-2$ in the presence of the inhibitors. RNA was extracted to assess viral gene transcription. Figure 3 shows by phylogenetic tree analysis that all five selected genes clustered in the same clade as CyHV-2. As shown in Figure 4A, ORF35, ORF72, and ORF78 expression was inhibited in the samples treated with CHX at 12-15 $\mu \mathrm{g} / \mathrm{mL}$, whereas CHX-treatment did not affect ORF54 and ORF121 transcription. In addition, the transcription of ORF72 was also inhibited by Ara-C at all test concentrations from 180 to $300 \mu \mathrm{g} / \mathrm{mL}$, whereas Ara-C had no effect on ORF35, ORF54, ORF78, and ORF121 expression (Figure 4B). The results from samples treated with CHX combined with Ara-C confirmed that ORF72, encoding a major capsid protein of CyHV-2, is a viral L gene. As shown in Figure 4, ORF78 and ORF121 were confirmed as CyHV-2 E and IE genes, which contrasted with CyHV-3. The above data showed that CHX $(12 \mu \mathrm{g} / \mathrm{mL})$ combined with Ara-C $(300 \mu \mathrm{g} / \mathrm{mL})$ could be used efficiently in RyuF-2 cells to screen for viral IE genes. 


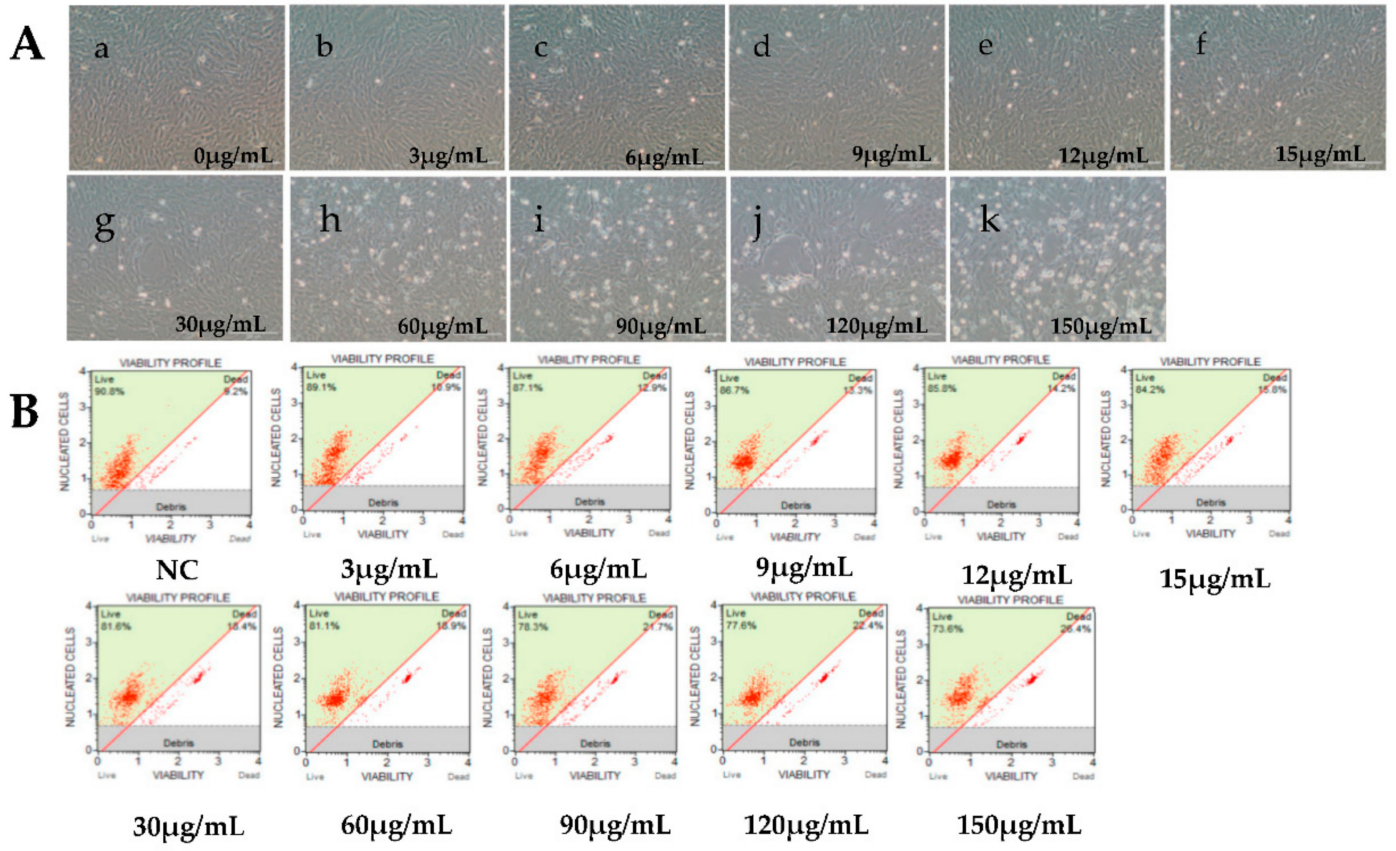

Figure 1. Effects of cycloheximide (CHX) at different concentrations on RyuF-2 cell viability. Cells were treated with $\mathrm{CHX}$ to inhibit protein synthesis in order to screen for immediately genes. Cell viability was determined under a microscope after $14 \mathrm{~h}$ of treatment with the different concentrations of $\mathrm{CHX}$ (5 150 $\mu \mathrm{g} / \mathrm{mL})$. (A, a-k), images of cell cultures under various $\mathrm{CHX}$ concentrations. (B) Corresponding cell viability graphs.

A
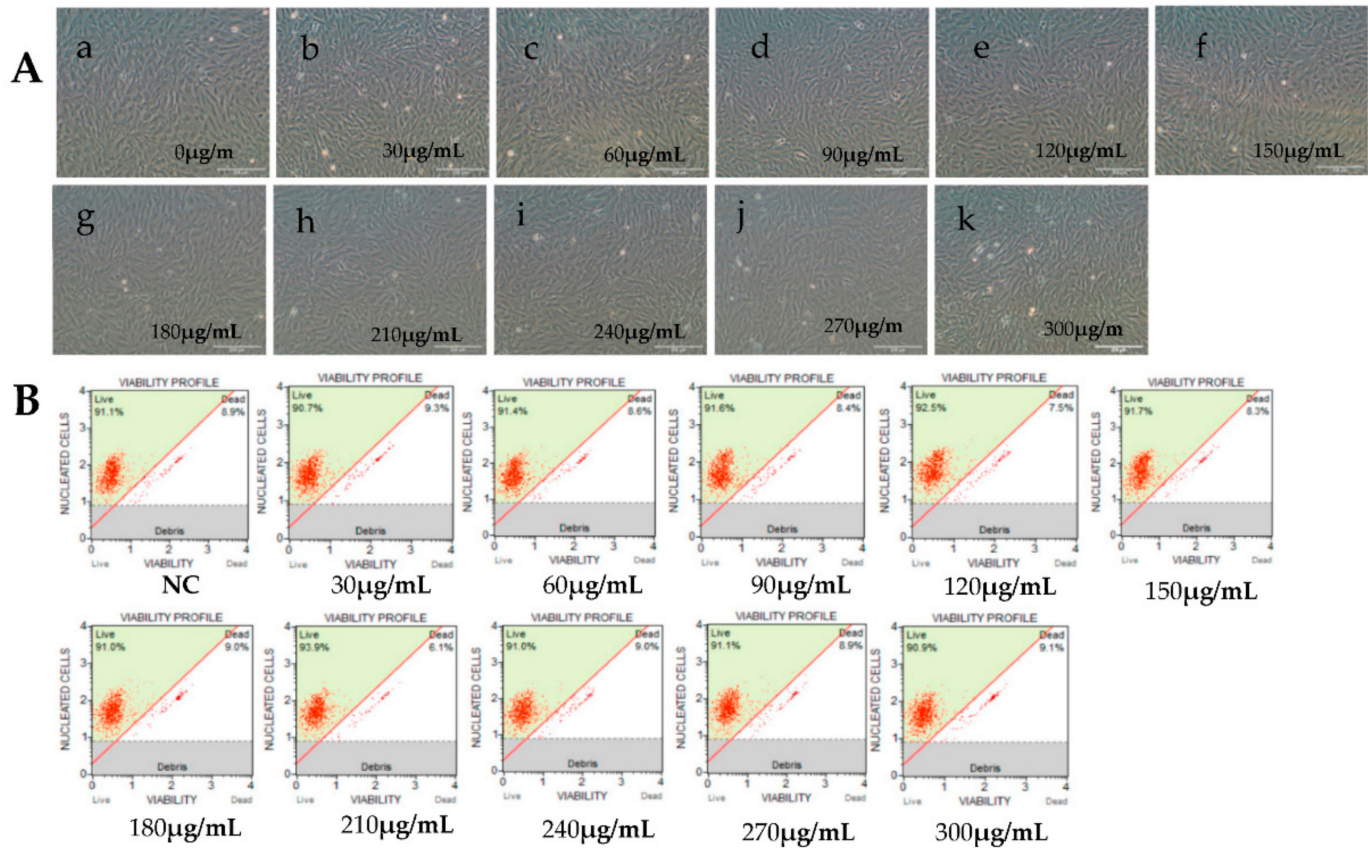

Figure 2. Effects of cytarabine injection (Ara-C) at different concentrations on RyuF-2 cell viability. Ara-C hinders the action of DNA polymerase and inhibits DNA synthesis. Cell viability was determined under a microscope after $14 \mathrm{~h}$ of treatment with the different concentrations of Ara-C $(0 \sim 300 \mu \mathrm{g} / \mathrm{mL})$. (A, a-k), images of cell cultures under various Ara-C concentrations. (B) Corresponding cell viability graphs. 

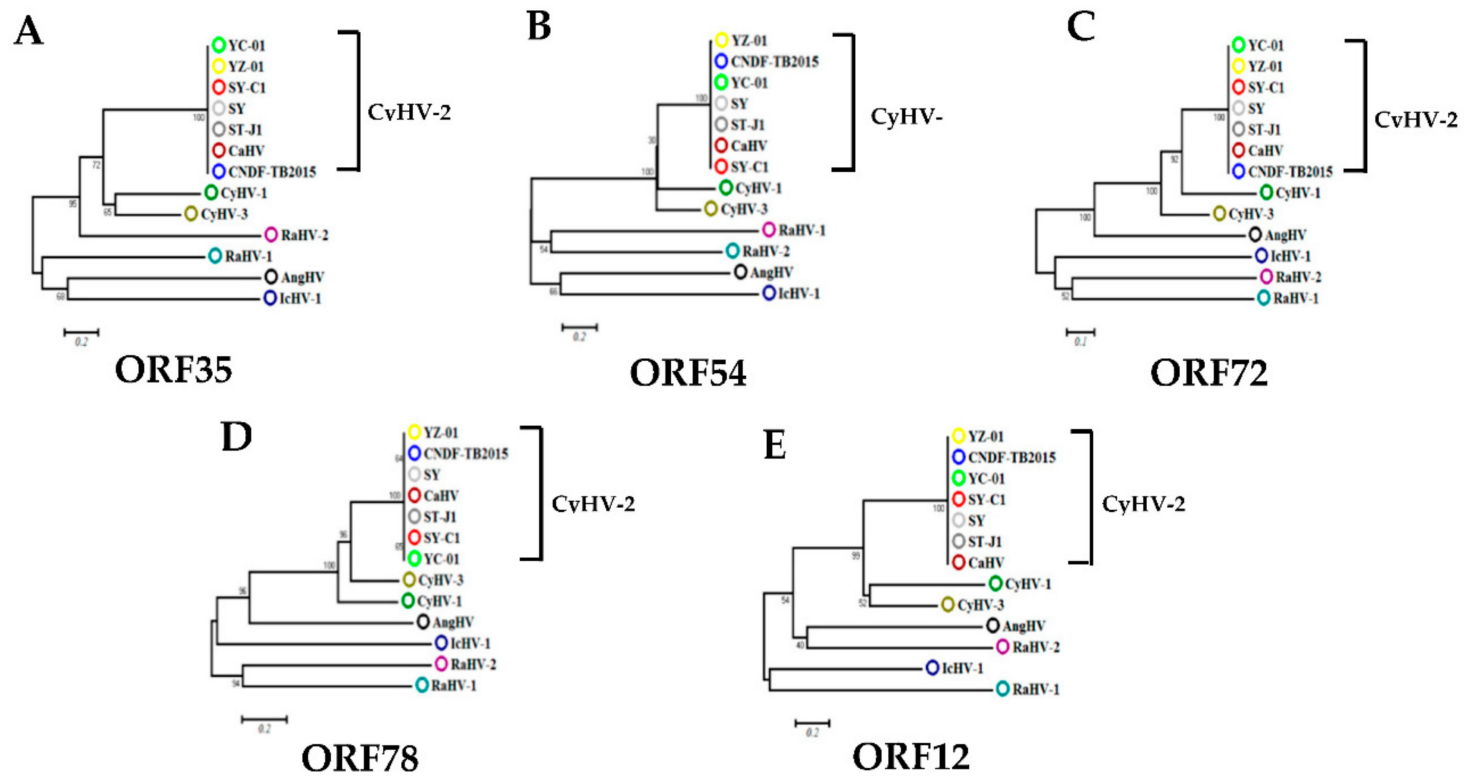

Figure 3. Phylogenetic analysis of five ORFs from CyHV-2. The Phylogenetic trees (A-E) were constructed using the neighbor-joining method in MEGA7 based on five ORFs from CyHV-2 (SY (GenBank accession no. KT387800), ST-J1 (NC_019495), SY-C1 (KM200722), CaHV (KU199244), YC-01 (MN593216)), CyHV1 (NC_019491), CyHV3 (NC_009127), AngHV1 (Anguillid herpesvirus-1; FJ940765), RaHV1 (Ranid herpesvirus-1; NC_008211), RaHV2 (Ranid herpesvirus-2; NC_008210), and IcHV1 (Ictalurid Herpesvirus 1; NC_001493). Branch lengths are proportional to evolutionary distance showing the divergence among different species.

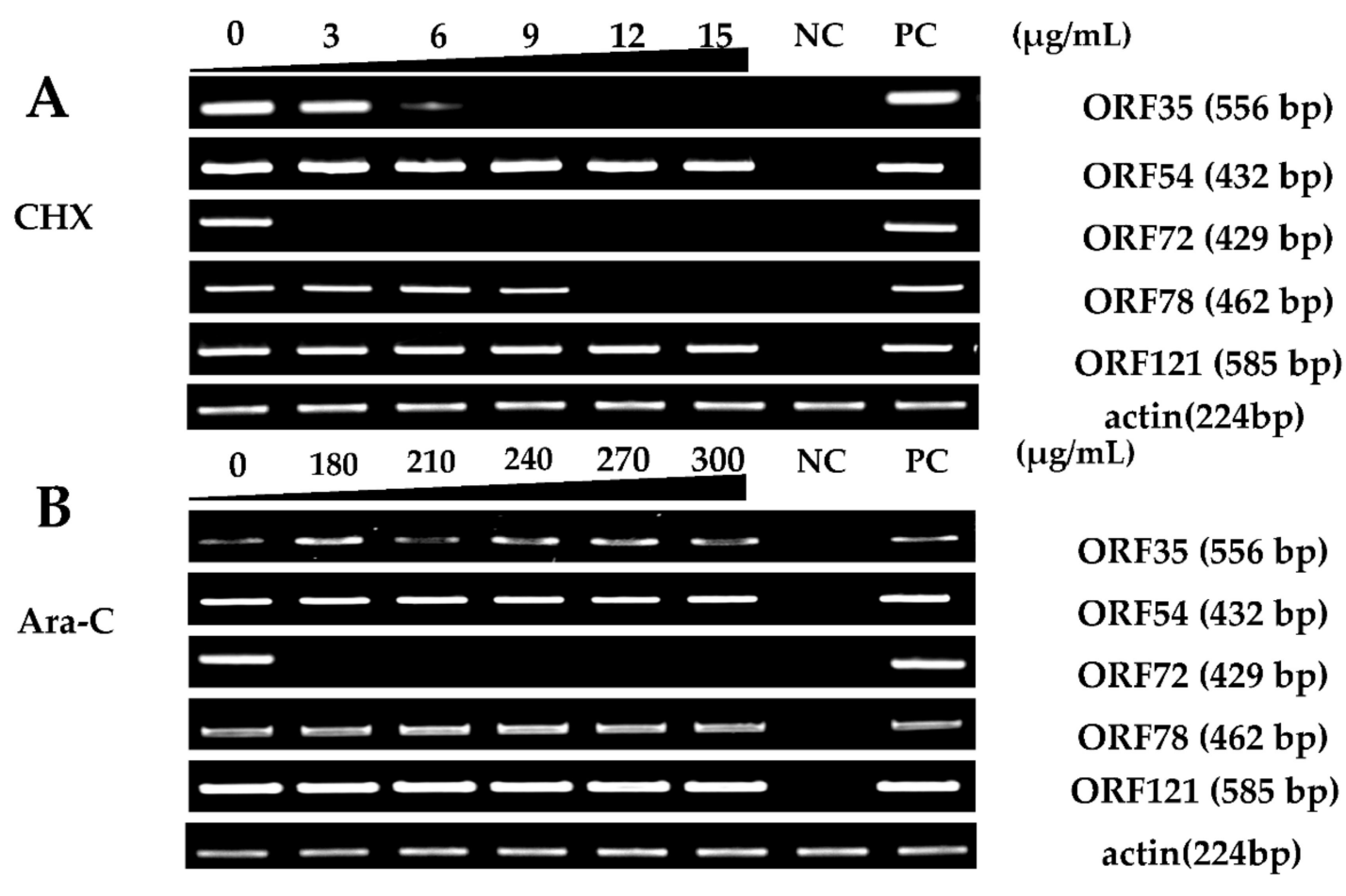

Figure 4. Effective concentration screening of the inhibitors. Gene expression differences of five selected CyHV-2 genes in infected RyuF-2 cells were obtained using Real-Time Reverse Transcription (RT-PCR) under different concentrations of CHX (0 to $15 \mu \mathrm{g} / \mathrm{mL})$ (A) or Ara-C (0 to $300 \mu \mathrm{g} / \mathrm{mL})$ (B) treatment. Treatment of infected cells with 12 15 $\mu \mathrm{g} / \mathrm{mL}$ CHX or 180 300 $\mu \mathrm{g} / \mathrm{mL}$ Ara-C inhibited the expression of certain genes. The gene encoding actin was used as an internal control. NC: negative control; PC: CyHV-2 DNA used as positive control. 
To confirm the effects of $\mathrm{CHX}$ and Ara-C on viral replication, infected cells treated with $\mathrm{CHX}$ $(12 \mu \mathrm{g} / \mathrm{mL})$ and Ara-C (300 $\mu \mathrm{g} / \mathrm{mL})$ before and at eight hours after infection were collected to investigate virus replication using transmission electron microscopy. As shown in Figure 5A,B, a large number of typical viral particles were observed in the RyuF-2 cells of the control group (without inhibitor). As expected, Figure 5C-F show no obvious particles in the inhibitor treatment groups compared with those in the control group. These data are consistent with qRT-PCR detection shown in Figure 4.

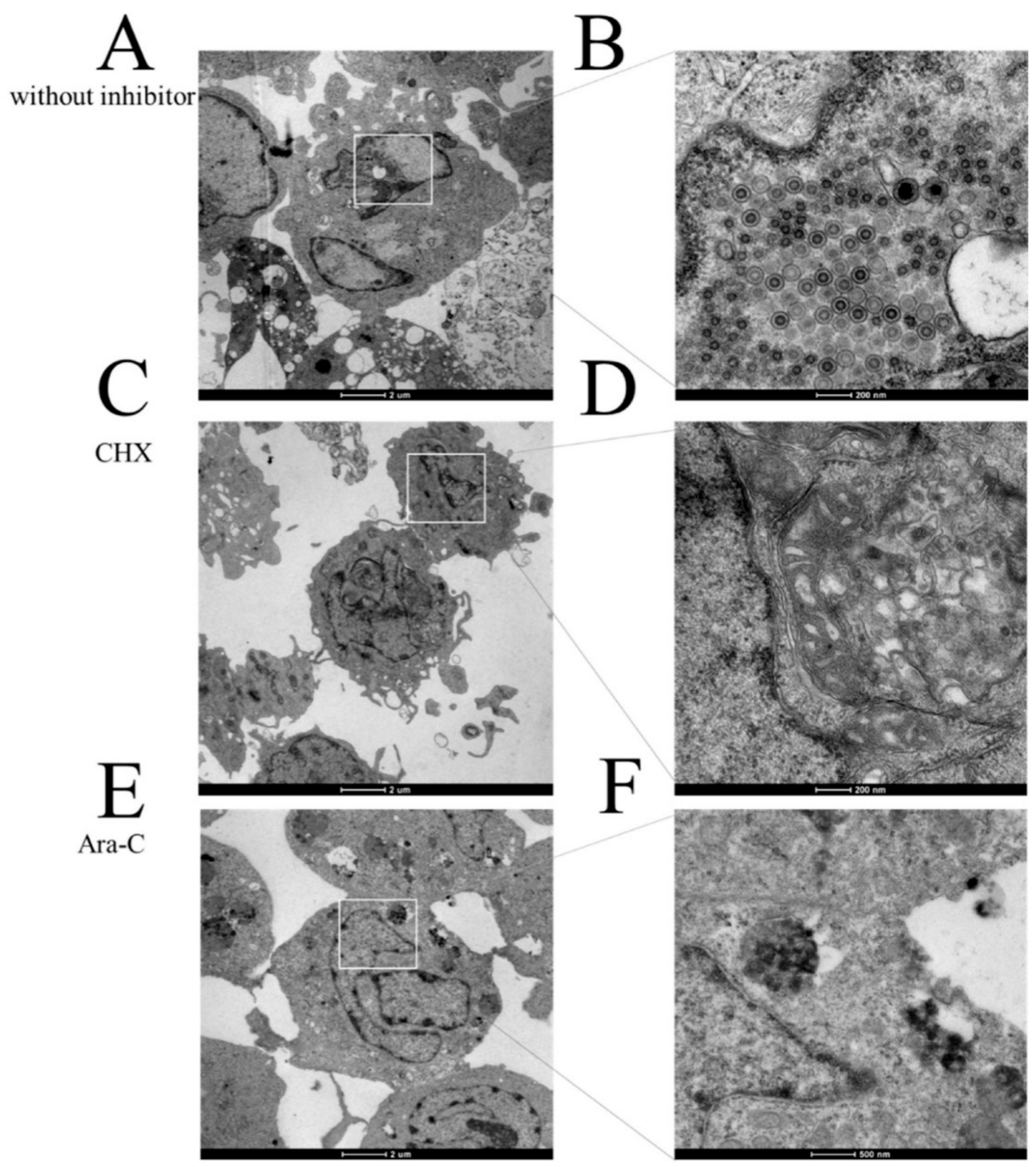

Figure 5. Action of $\mathrm{CHX}$ and Ara-C on progeny virus production. (A,B) Transmission electron microscopy image of the uptake of CyHV-2 into RyuF-2 cells (including a magnified image of a region of the first panel). (C,D) Transmission electron microscopy image of the uptake of CyHV-2 into RyuF-2 cells in the presence of $\mathrm{CHX}$ (including a magnified image of a region of the first panel). (E,F) Transmission electron microscopy image of the uptake of CyHV-2 into RyuF-2 cells in the presence of Ara-C (including a magnified image of a region of the first panel).

CyHV-2 ORF expression was examined for three groups: the control group (without inhibitor), the CHX $(12 \mu \mathrm{g} / \mathrm{mL})$ treatment group, and the Ara-C $(300 \mu \mathrm{g} / \mathrm{mL})$ treatment group. RyuF-2 cells at eight hours post infection with CyHV-2 were subjected to mRNA extraction followed by RNA-seq analysis, which produced several million high quality reads for each sample (Table 2 ). The cleaned reads were analyzed and mapped to the CyHV-2 genome. As shown in Figure 6, Table 2, and Supplementary Materials Table S1, all 150 annotated ORFs from CyHV-2 ST-J1 were completely sequenced in the control 
group, which indicated that CyHV-2 DNA synthesis had been achieved at eight hours post-infection. As expected, fewer ORFs were expressed in the CHX groups compared with those expressed in the Ara-C group (61 vs. 127) (Figure 6 and Table S1). Thus, these 61 ORFs were identified as candidate IE genes in CyHV-2. Table S1 provides detailed information concerning the candidate IE genes.

Table 2. Read quality and mapping results for High-throughput sequencing. Group "1"was infected with CyHV-2. Group "A" was treated with $300 \mu \mathrm{g} / \mathrm{mL}$ A-arc and infected with CyHV-2. Group "C" was CyHV-2 infected, treated with $12 \mu \mathrm{g} / \mathrm{mL}$ CHX inhibition.

\begin{tabular}{cccccc}
\hline Sample & $\begin{array}{c}\text { NCBI } \\
\text { BioSample }\end{array}$ & Treatment & Total Reads & Cleaned Reads & $\begin{array}{c}\text { Mapped to } \\
\text { CyHV-2 Genome }\end{array}$ \\
\hline 1 & SAMN14501569 & infectin & 98539532 & 98128002 & $26583(0.2697 \%)$ \\
A & SAMN14501570 & A-arc & 100866928 & 100455032 & $5887(0.1253 \%)$ \\
C & SAMN14501571 & CHX & 46974030 & 46710488 & $2969(0.0029 \%)$ \\
\hline
\end{tabular}

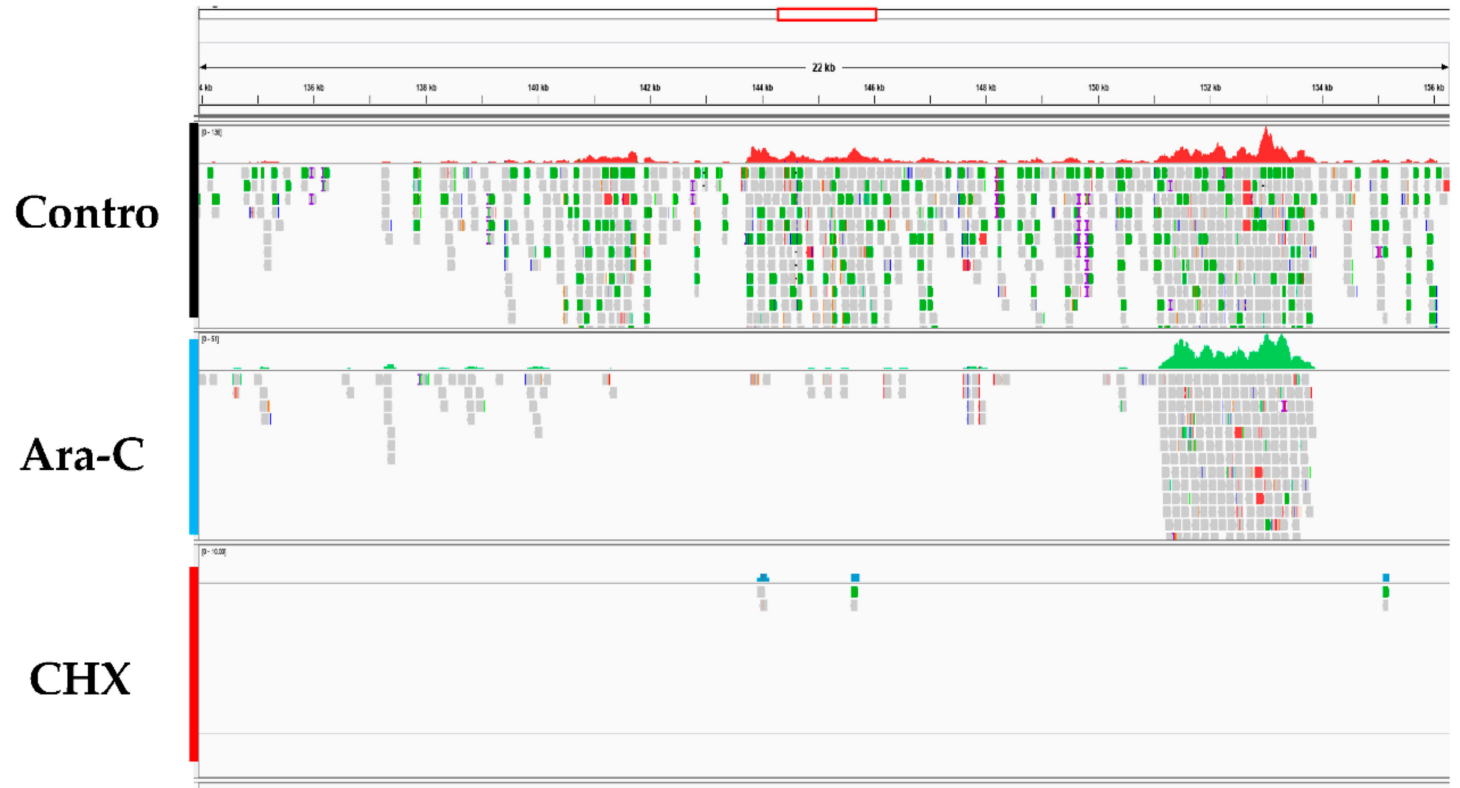

Figure 6. High-throughput sequencing data analysis. Panels show the differences in transcript expression levels among the groups after treatment with different inhibitors. Control: Infected CyHV-2 group; Ara-C: Infected with CyHV-2 and treated with cytarabine; CHX: Infected with CyHV-2 and treated with cycloheximi.

\subsection{CyHV-2 IE Genes Confirmation Using qRT-PCR}

Subsequently, the 61 candidate CyHV-2 IE genes and other candidate E and L genes were subjected to qRT-PCR analysis. As shown in Figures 4 and 7, among the 61 candidate viral IE genes from RNA-Seq results, five genes (ORF54, ORF121, ORF141, ORF147, and ORF155) were detected in the presence of both CHX and Ara-C during CyHV-2 infection. Figure 7A shows that 36 ORFs could be detected in the cells treated with Ara-C but without CHX. Additionally, 39 ORFs were not detected in both the CHX treated and Ara-C treated samples (Figure 7B). Ultimately, the five genes listed above were identified as the CyHV-2 IE genes. 
A

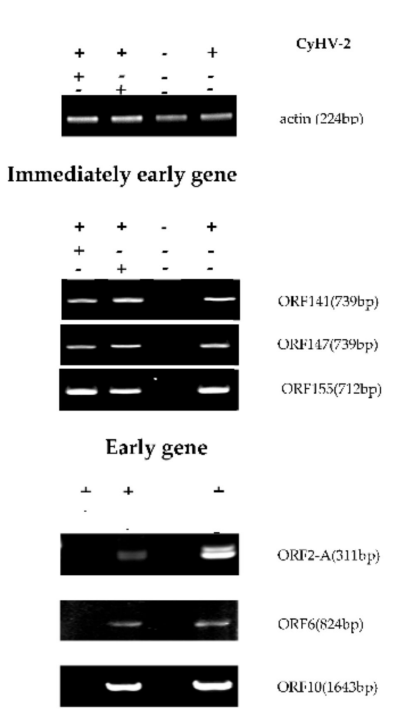

B

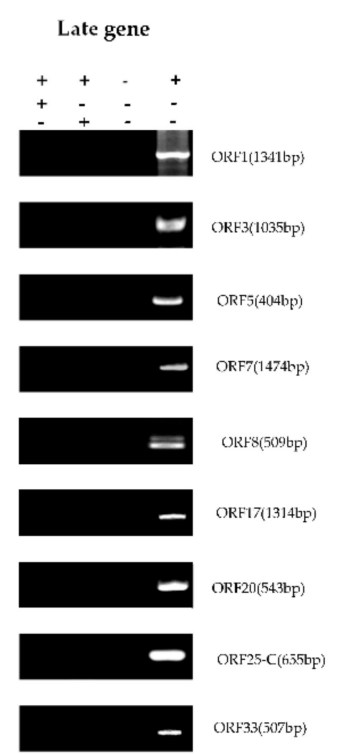

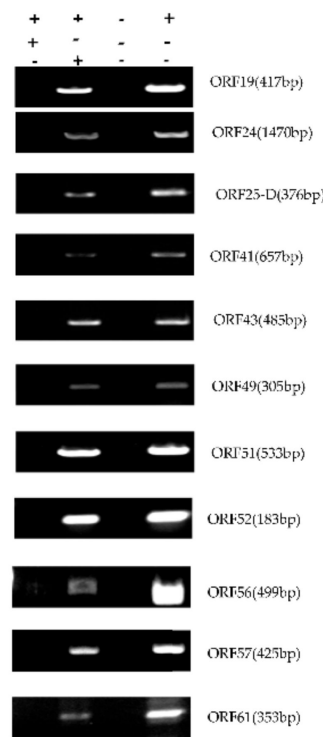
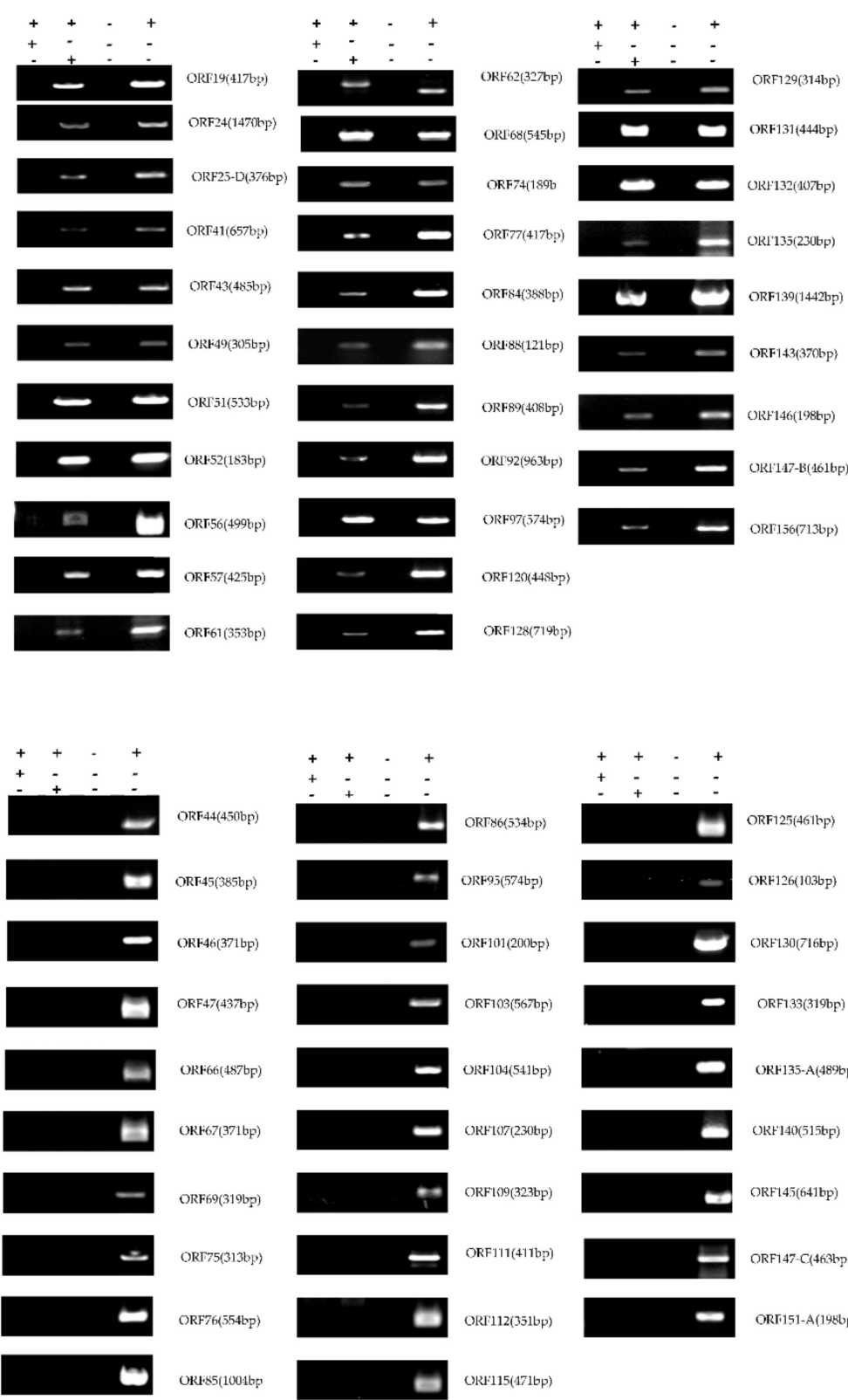

ORP115(471bp)

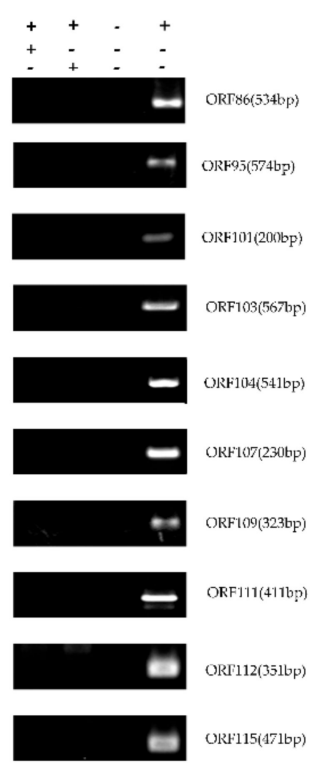

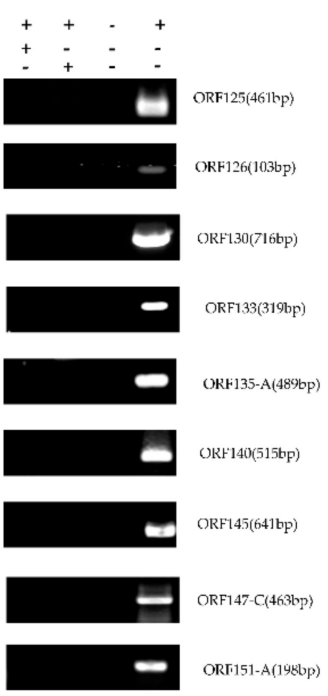

Figure 7. Classification of gene expression distinct phases of CyHV-2 base on inhibitors treatment. According to the transcriptome results, the gene expression in different inhibitor treatment groups were validated by RT-PCR. Specific primers for different ORFs were designed to detect CyHV-2 gene expression and classify the phases of $\mathrm{CyHV}-2$ gene expression. $\mathrm{CHX}$ can inhibit the expression of genes other than the early genes of the virus by inhibiting protein synthesis. Early gene expression cannot be suppressed by Ara-C. The gene encoding actin was used as an internal reference. (A) Immediate-early

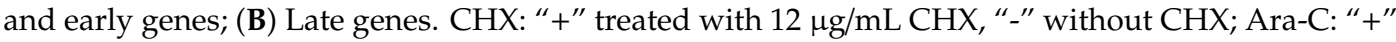
treated with 300 g/mL Ara-C, "-" without Ara-C; CyHV-2: "+" infected with CyHV-2; "-" uninfected.

Bioinformatic analysis using the SMART (http://smart.emblheidelberg.de), NCBI (https://www. ncbi.nlm.nih.gov/), and Protein Blast http://blast.ncbi.nlm.nih.gov/Blast.cgi) databases showed that three of the proteins encoded by the CyHV-2 IE genes contained important function motifs. The ORF54 predicted protein contains a zinc finger motif that suggests a DNA binding function. This gene structure is the same as that found in CyHV-3 ORF54. Zinc fingers are a common DNA binding domain found in many transcription factors; the results indicated that ORF54 plays a key role in the regulation of other viral genes or host genes. ORF121 was predicted to express a member of the GAGA binding 
protein-like family, which have a zinc-binding DNA interaction domain. Additionally, it contains an AAA domain, which is a potential ATP binding and hydrolysis domain. Thus, viral ORF121 might generate the energy required for translocation. Furthermore, ORF141 encodes a CyHV-2 large subunit of ribonucleotide reductase annotated to be involved in nucleotide metabolism, DNA, and RNA. The other two viral IE genes (ORF147 and ORF155) had no known functional domains. The biological function analysis of all 150 viral ORFs is shown in Supplementary Table S1.

\subsection{IE Gene Temporal Expression during CyHV-2 Infection}

Cell were sampled at various times post infection, and RNA and cDNA were prepared. Figure 8 shows that all five CyHV-2 IE genes were initially transcribed within $30 \mathrm{~min}$ of infection. As determined by qPCR, the expression of all five viral IE genes in CyHV-2-infected cells started at $0.5 \mathrm{~h}$, which is consistent with the qRT-PCR results (Figure 9A). As expected, all the viral IE genes were detected in the $\mathrm{CHX}$ and Ara-C treated groups. As controls, qPCR (Figure 9B) showed that the viral E genes (ORF80, ORF89, and ORF97) could be detected at $1 \mathrm{~h}$ post-infection, and most of them appeared between 1 and $2 \mathrm{~h}$ post-infection. As shown in Figure 9C, viral L genes (ORF7-1 and ORF147-C) appeared at $6 \mathrm{~h}$ post-infection. Additionally, as shown in Figure 9B and C, viral E genes could be detected in Ara-C treated samples but not CHX-treated samples, while the viral L genes only appeared in non-treated samples, which was consistent with the previous qRT-PCR results. Consequently, temporal expression analysis clearly distinguished the chronological order of CyHV-2 IE, E, and L gene expression.

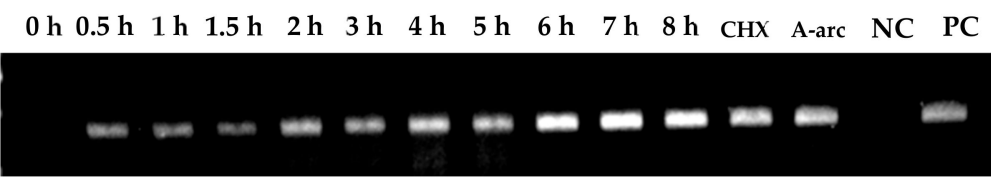

ORF54 (432 bp)

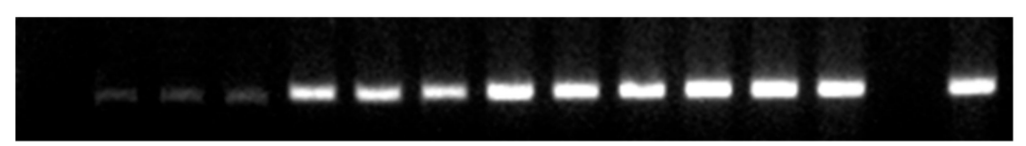

ORF121 (585 bp)

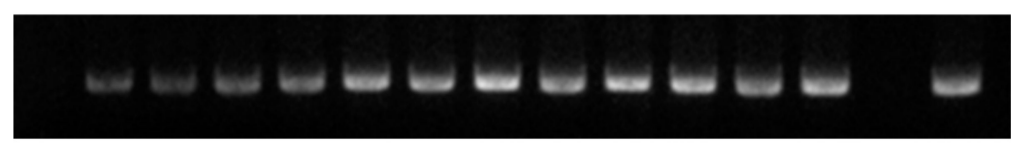

ORF141 (739 bp)

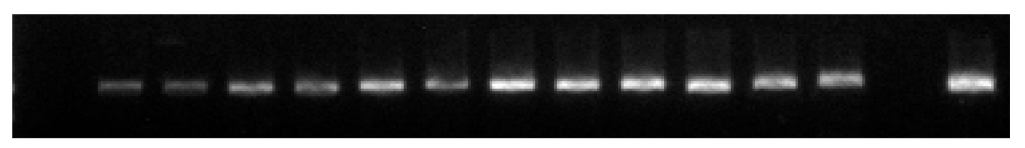

ORF147 (739 bp)

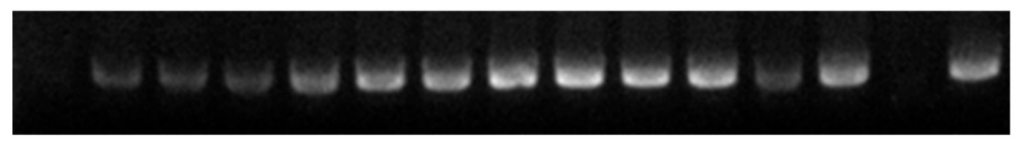

ORF155 (712 bp)

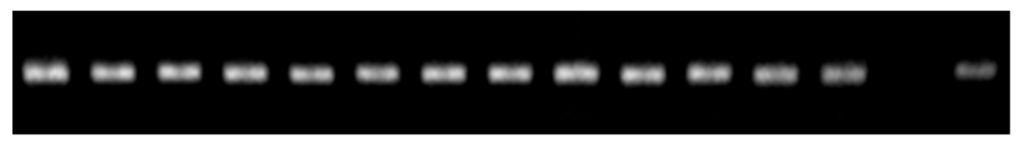

actin (224 bp)

Figure 8. Time course of immediate-early (IE) gene expression during viral infection. At various timepoints, total RNA was extracted from CyHV-2-infected RyuF-2 cells. RT-PCR was used to detect the expression of control genes and all six IE genes. CHX: treated with $12 \mu \mathrm{g} / \mathrm{mL} \mathrm{CHX;} \mathrm{Ara-C:} \mathrm{treated}$ with $300 \mu \mathrm{g} / \mathrm{mL}$ Ara-C; NC: uninfected cells; PC: Positive control comprising CyHV-2 DNA. 

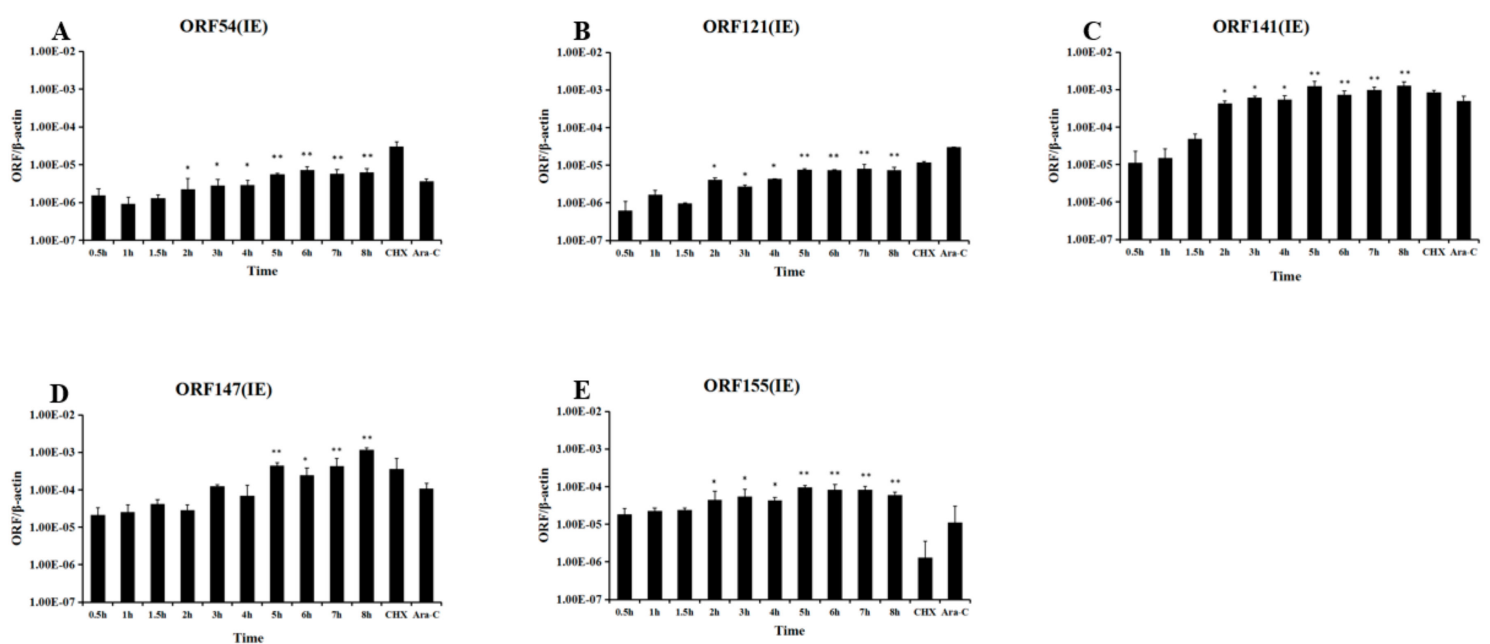

(a)
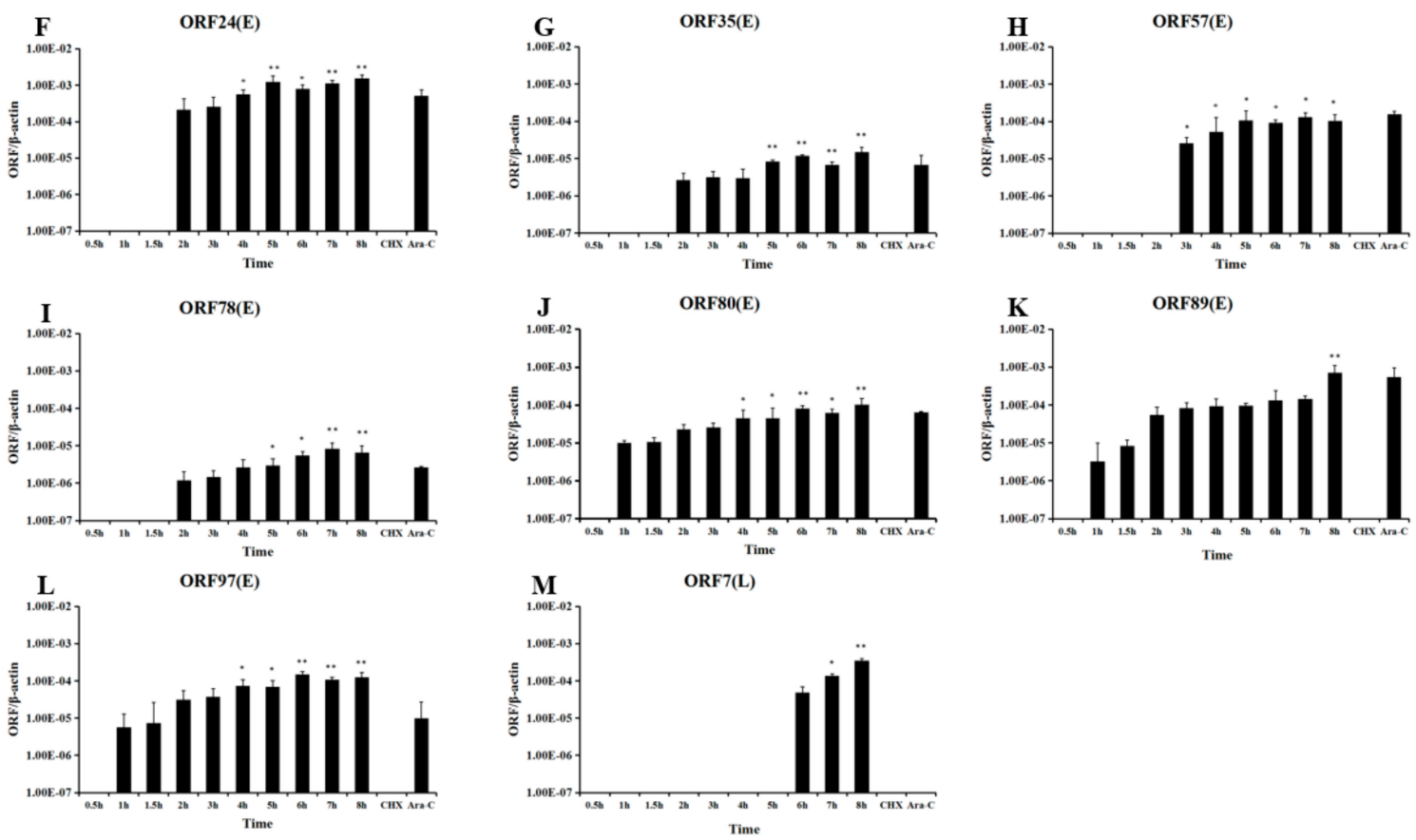

(b)

Figure 9. Quantification of CyHV-2 ORF transcripts at indicated time points. Cells were infected with CyHV-2 and treated with no inhibitor, $\mathrm{CHX}$ at $300 \mu \mathrm{g} / \mathrm{mL} \mathrm{CHX}$ or Ara-C at $12 \mu \mathrm{g} / \mathrm{mL}$ Ara-C before RNA extraction and RT-PCR, followed by cDNA synthesis. The amount of amplified cDNA was normalized to that of the actin mRNA present in the same sample. Genes that were expressed up to $2 \mathrm{~h}$ are divided into immediate-early (IE) genes (A): ORF54, ORF121, ORF141, ORF147, and ORF155; genes that begin to be expressed between 2 and $4 \mathrm{~h}$ are early (E) genes (B): ORF24, ORF35, ORF57, ORF78, ORF80, ORF89, and ORF97; and genes that begin to be expressed after $4 \mathrm{~h}$ are late (L) genes (C): ORF7. Error bars represent the standard deviation of the mean of experiments performed in triplicate. o significant difference, ${ }^{*} p \leq 0.05$ and ${ }^{* *} p \leq 0.01$.

\section{Discussion}

Upon infection, viruses with large DNA genomes express their genes according to a tightly regulated cascade, in which numbers of genes are coordinately transcribed. IE gene products are involved in 
regulating the expression of $\mathrm{E}$ and $\mathrm{L}$ genes or modulation of host cell function [16]. Therefore, the viral IE genes of DNA viruses play an essential role in viral replication. For example, the capsid protein VP16 of the herpes simplex virus type 1 (HSV-1) could recruit the host transcription machinery to initiate the replication of viral IE genes, such as infected cell protein 0 (ICP0), ICP4, ICP27, and ICP47. ICP0 could induce extensive structural and biological changes to Nuclear domain 10 (ND10). The HSV IE gene product ICP4 acts as a major transcriptional activator that is essential to regulate viral $\mathrm{E}$ and $\mathrm{L}$ genes. ICP27 promotes viral infection through splicing, processing, and mRNA export [17]. The present study explored CyHV-2 IE genes through high-throughput sequencing combined with the use of inhibitors.

$\mathrm{CHX}$, a protein synthesis inhibitor, has been widely used to identify viral IE genes, such as in CyHV-3, WSSV, and HSV-1 [7,18-21]. The nucleoside analog Ara-C can be used to differentiate between viral $\mathrm{E}$ and $\mathrm{L}$ genes [8]. Shibata et al. [22] reported that the RyuF-2 cell line exhibits a higher susceptibility to CyHV-2 infection than other cells; however, EPC, FHM, and BF-2 cells could not be used to propagate the virus, even at a high titer of the CyHV-2. In this study, we employed the CyHV-2-infected RyuF-2 in vitro model to classify the temporal expression patterns of virus genes during infection. Cytotoxicity assays using RyuF-2 cells showed that $\mathrm{CHX}$ and Ara-C could be used safely below concentrations of $15 \mu \mathrm{g} / \mathrm{mL}$ and $300 \mu \mathrm{g} / \mathrm{mL}$. In our previous study, ORF121 showed the highest expression in almost all tested tissues during viral infection [23]. In previous research on CyHV-3, Ilouze et al. [8] identified ORF54 as a viral IE gene; ORF35, ORF72, and ORF121 were identified as E genes; and ORF78 was identified as an L gene. ORF54, ORF72, and ORF78 share around $50 \%$ sequence similarity with CyHV-2 and CyHV-3. In addition, CyHV-2 ORF54 contains a conserved putative zinc-binding domain, as it does in CyHV-3. ORF72 from CyHV-2 or CyHV-3 encodes the major capsid protein and shows high immunogenicity. Similar to CyHV-3, the capsid protein pORF78 is abundant in mature CyHV-2 particles [24]. In addition, ORF35 is significantly different between CyHV-2 and CyHV-3. Consequently, ORF54, ORF121, ORF72, ORF78, and ORF35 were selected to evaluate the efficiency of the screening model. As shown in Figure 5, the transcription of ORF54 and ORF121 were not affected by different concentrations of $\mathrm{CHX}$ or Ara-C, classifying them as IE genes. As the $\mathrm{CHX}$ concentration in the medium increased, the transcription of ORF35, ORF72, and ORF78 were inhibited (Figure 5). Furthermore, ORF72, but not ORF35 and ORF78, could be inhibited by Ara-C at $300 \mu \mathrm{g} / \mathrm{mL}$. Taken together with the results described above, we concluded that ORF35 and ORF78 should be classified as E genes, and ORF72 should be classified as an L gene. Consequently, $\mathrm{CHX}$ at $12 \mu \mathrm{g} / \mathrm{mL}$ and Ara-C at $300 \mu \mathrm{g} / \mathrm{mL}$ could be used to distinguish the CyHV-2 IE, E, and L genes. Table 2 shows that all 150 ORFs of CyHV-2 annotated previously [25] were identified in the control group. The high-throughput sequencing detected $61 \mathrm{ORFs}$ in the CHX treatment group and 127 ORFs in Ara-C treatment group. Finally, temporal expression analysis and qRT-PCR identified $5 \mathrm{IE}, 34 \mathrm{E}$, and $39 \mathrm{~L}$ genes (Figures 7 and 8).

In this study, ORF54, ORF121, ORF141, ORF147, and ORF155 were identified as viral IE genes. Several lines of evidence support this conclusion. First, the mRNAs for these five ORFs were detected in the groups with blocked viral protein synthesis (Table 2, Figures 5 and 7), which is a characteristic of viral IE genes. Second, the ORFs were first transcribed earlier than the other viral ORFs (Figure 8). Previous work has shown that ORF121 is the most abundant protein in moribund fish infected with CyHV-2 [26]. Similarly, ORF121 was also one of the most highly expressed ORFs during CyHV-3 infection in an acute infection group [27]. As shown in Figure 8B, the transcription of the IE gene ORF121 started earlier than that of the other viral non-IE genes. This suggested that ORF121 might exert regulatory effects on viral non-IE genes or host innate immunity genes. Similarly to CyHV-3, ORF54 and ORF155 were classified as viral IE genes. As shown in Table 2, ORF54 contains a putative zinc-binding domain, suggesting it plays a role in regulating other viral or host genes; however, no functional information was available for ORF155. ORF141 encodes a subunit of ribonucleotide reductase that might be essential for DNA synthesis. In addition, Figure 8E-L shows that the transcription of viral E genes started at around $2 \mathrm{~h}$ post infection. As shown in Figure 8M,N, viral L genes appeared at $6 \mathrm{~h}$ post infection. This suggested that the replication of CyHV-2, like other large DNA viruses, starts with viral IE gene expression, followed by the expression of $\mathrm{E}$ and L genes. Large DNA viruses typically carry hundreds of genes, and IE genes encode proteins required for the regulation of viral gene expression. 
Among the five CyHV-2 IE genes, two (ORF54 and ORF155) are consistent with the CyHV-3 genes annotated by Ilouze et al. [8]. The other three CyHV-2 IE genes (ORF121, ORF141, and ORF147) identified in this study were different from those of CyHV-3. These three viral genes were considered as $\mathrm{E}$ genes in CyHV-3. Moreover, 10 out of the $15 \mathrm{CyHV}-3 \mathrm{IE}$ genes were confirmed to have different

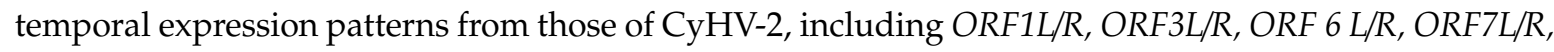
ORF8L/R, ORF10, ORF24, ORF88, and ORF112. All these ten CyHV-3 IE genes contain different functional domains from CyHV-2, based on the bioinformatic analysis. The other three CyHV-3 IE genes (ORF9, ORF11, and ORF149) share no sequence homology with those of CyHV-2.

In future studies, the function of viral IE genes should be explored to fully determine the molecular mechanism of CyHV-2 infection. However, the biological function of viral IE genes in CyHV-2 infection is currently unclear. CyHV-2 can lead to acute infection, persistent infection, and latent infection. A recent report by Wei et al. recommended that a persistent infection could re-emerge as an acute infection under certain conditions, such as a dramatic temperature shift. Currently, the complex molecular mechanisms by which CyHV-2 establishes acute infection, persistent infection, or latent infection are incompletely understood. Taken together, the results of the present study provide important insights into the pathogenesis of CyHV-2. Future studies should investigate the functions of CyHV-2 IE genes, such as ORF54 and ORF121, to provide a deeper understanding of CyHV-2's biology and to achieve control of the disease.

Supplementary Materials: The following are available online at http://www.mdpi.com/1999-4915/12/9/994/s1. Supplementary data included for this article can viewed online at https:/www.ncbi.nlm.nih.gov/sra/?term= PRJNA621366. Table S1: characteristics of CyHV-2 gene.

Author Contributions: H.W. and L.L. were responsible for the experimental design, analyses, and interpretation of the data. H.W. drafted the manuscript. R.T., H.W., B.W. and J.Y. performed the experiments. All authors have read and agreed to the published version of the manuscript.

Funding: The present study received grant support from the Young Elite Scientists Sponsorship Program by CAST (D-8005-19-0012); Technology Innovation Action Program of Shang Hai, China(19YF1419300); National Key R\&D Program of China (2019YFD0900104); The Earmarked Fund for China Agriculture Research System (CARS-45-19).

Acknowledgments: We thank Mikio Tanaka (Tokyo University of Marine Science and Technology, Minato-ku, Tokyo, Japan) for kindly providing RyuF-2 cell line and CyHV-2 ST-J1 isolate used in this work.

Conflicts of Interest: The authors declare that there are no conflicts of interest.

\section{References}

1. Jung, S.J.; Miyazaki, T. Herpesviral Hematopoietic Necrosis of Goldfish, Carassius-Auratus (L). J. Fish Dis. 1995, 18, 211-220. [CrossRef]

2. Goodwin, A.E.; Merry, G.; Sadler, J. Detection of the herpesviral hematopoietic necrosis disease agent (Cyprinid herpesvirus 2) in moribund and healthy goldfish: Validation of a quantitative PCR diagnostic method. Dis. Aquat. Org. 2006, 69, 137-143. [CrossRef] [PubMed]

3. Jeffery, K.R.; Bateman, K.S.; Bayley, A.; Feist, S.W.; Hulland, J.; Longshaw, C.; Stone, D.; Woolford, G.; Way, K. Isolation of a cyprinid herpesvirus 2 from goldfish, Carassius auratus (L.), in the UK. J. Fish Dis. 2007, 30, 649-656. [CrossRef] [PubMed]

4. Wu, T.; Ding, Z.; Ren, M.; An, L.; Xiao, Z.; Liu, P.; Gu, W.; Meng, Q.; Wang, W. The histo- and ultra-pathological studies on a fatal disease of Prussian carp (Carassius gibelio) in mainland China associated with cyprinid herpesvirus 2 (CyHV-2). Aquaculture 2013, 412, 8-13. [CrossRef]

5. Stephens, F.; Raidal, S.R.; Jones, B. Haematopoietic necrosis in a goldfish (Carassius auratus) associated with an agent morphologically similar to herpesvirus. Aust. Vet. J. 2004, 82, 167-169. [CrossRef]

6. Reed, A.N.; Izume, S.; Dolan, B.P.; LaPatra, S.; Kent, M.; Dong, J.; Jin, L. Identification of B Cells as a Major Site for Cyprinid Herpesvirus 3 Latency. J. Virol. 2014, 88, 9297-9309. [CrossRef]

7. Yuan, Y. Identification and characterization of herpesviral immediate-early genes. Adv. Struct. Saf. Stud. 2005, 292, 231-244. [CrossRef]

8. Ilouze, M.; Dishon, A.; Kotler, M. Coordinated and sequential transcription of the cyprinid herpesvirus-3 annotated genes. Virus Res. 2012, 169, 98-106. [CrossRef] 
9. Zeng, X.-T.; Chen, Z.-Y.; Deng, Y.-S.; Gui, J.; Zhang, Q.-Y. Complete genome sequence and architecture of crucian carp Carassius auratus herpesvirus (CaHV). Arch. Virol. 2016, 161, 3577-3581. [CrossRef]

10. Ito, T.; Kurita, J.; Ozaki, A.; Sano, M.; Fukuda, H.; Ototake, M. Growth of cyprinid herpesvirus 2 (CyHV-2) in cell culture and experimental infection of goldfish Carassius auratus. Dis. Aquat. Org. 2013, 105, 193-202. [CrossRef]

11. Davison, A.J.; Kurobe, T.; Gatherer, D.; Cunningham, C.; Korf, I.; Fukuda, H.; Hedrick, R.P.; Waltzek, T.B. Comparative Genomics of Carp Herpesviruses. J. Virol. 2012, 87, 2908-2922. [CrossRef] [PubMed]

12. Fang, Q.; Seng, E.K.; Ding, Q.Q.; Zhang, L.L. Characterization of infectious particles of grass carp reovirus by treatment with proteases. Arch. Virol. 2008, 153, 675-682. [CrossRef] [PubMed]

13. Grabherr, M.G.; Haas, B.J.; Yassour, M.; Levin, J.Z.; Thompson, D.A.; Amit, I.; Adiconis, X.; Fan, L.; Raychowdhury, R.; Zeng, Q.; et al. Full-length transcriptome assembly from RNA-Seq data without a reference genome. Nat. Biotechnol. 2011, 29, 644-652. [CrossRef] [PubMed]

14. Langmead, B.; Salzberg, S.L. Fast gapped-read alignment with Bowtie 2. Nat. Methods 2012, 9, 357-359. [CrossRef] [PubMed]

15. Kumar, S.; Stecher, G.; Tamura, K. MEGA7: Molecular Evolutionary Genetics Analysis Version 7.0 for Bigger Datasets. Mol. Biol. Evol. 2016, 33, 1870-1874. [CrossRef]

16. Li, D.F.; Zhang, M.C.; Yang, H.J.; Zhu, Y.B.; Xu, X. Beta-integrin mediates WSSV infection. Virology 2007, 368, 122-132. [CrossRef]

17. Wang, X.; Hennig, T.; Whisnant, A.W.; Erhard, F.; Prusty, B.K.; Friedel, C.C.; Forouzmand, E.; Hu, W.; Erber, L.; Chen, Y.; et al. Herpes simplex virus blocks host transcription termination via the bimodal activities of ICP27. Nat. Commun. 2020, 11, 293-313. [CrossRef]

18. Hagglund, R.; Roizman, B. Role of ICP0 in the Strategy of Conquest of the Host Cell by Herpes Simplex Virus 1. J. Virol. 2004, 78, 2169-2178. [CrossRef]

19. Li, F.; Li, M.; Ke, W.; Ji, Y.; Bian, X.; Yan, X. Identification of the immediate-early genes of white spot syndrome virus. Virology 2009, 385, 267-274. [CrossRef]

20. Lin, F.; Huang, H.; Xu, L.; Li, F.; Yang, F. Identification of three immediate-early genes of white spot syndrome virus. Arch. Virol. 2011, 156, 1611-1614. [CrossRef]

21. Liu, W.-J.; Chang, Y.-S.; Wang, C.-H.; Kou, G.-H.; Lo, C.-F. Microarray and RT-PCR screening for white spot syndrome virus immediate-early genes in cycloheximide-treated shrimp. Virology 2005, 334, 327-341. [CrossRef] [PubMed]

22. Shibata, T.; Nanjo, A.; Saito, M.; Yoshii, K.; Ito, T.; Nakanishi, T.; Sakamoto, T.; Sano, M. In vitro characteristics of cyprinid herpesvirus 2: Effect of kidney extract supplementation on growth. Dis. Aquat. Org. 2015, 115, 223-232. [CrossRef] [PubMed]

23. Wang, H.; Xu, L.; Lu, L. Detection of cyprinid herpesvirus 2 in peripheral blood cells of silver crucian carp, Carassius auratus gibelio(Bloch), suggests its potential in viral diagnosis. J. Fish Dis. 2015, 39, 155-162. [CrossRef] [PubMed]

24. Gao, W.; Wen, H.; Wang, H.; Lu, J.; Lu, L.; Jiang, Y. Identification of structure proteins of cyprinid herpesvirus 2. Aquaculture 2020, 523, 735184. [CrossRef]

25. Davidovich, M.; Dishon, A.; Ilouze, M.; Kotler, M. Susceptibility of cyprinid cultured cells to cyprinid herpesvirus 3. Arch. Virol. 2007, 152, 1541-1546. [CrossRef] [PubMed]

26. Xu, L.; Podok, P.; Xie, J.; Lu, L. Comparative analysis of differential gene expression in kidney tissues of moribund and surviving crucian carp (Carassius auratus gibelio) in response to cyprinid herpesvirus 2 infection. Arch. Virol. 2014, 159, 1961-1974. [CrossRef] [PubMed]

27. Neave, M.J.; Sunarto, A.; McColl, K.A. Transcriptomic analysis of common carp anterior kidney during Cyprinid herpesvirus 3 infection: Immunoglobulin repertoire and homologue functional divergence. Sci. Rep. 2017, 7, 41531. [CrossRef]

(C) 2020 by the authors. Licensee MDPI, Basel, Switzerland. This article is an open access article distributed under the terms and conditions of the Creative Commons Attribution (CC BY) license (http://creativecommons.org/licenses/by/4.0/). 